\title{
ANL-79-8
}

\section{HYCSOS: A CHEMICAL HEAT PUMP AND ENERGY CONVERSION SYSTEM BASED ON METAL HYDRIDES}

1979 Status Report

\author{
by \\ Irving Sheft, Dieter M. Gruen, \\ and George Lamich
}

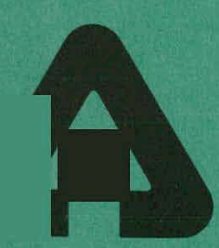

U OfC-AUA-USDOE

ARGONNE NATIONAL LABORATORY, ARGONNE, ILLINOIS

Prepared for the U. S. DEPARTMENT OF ENERGY under Contract W-31-109-Eng-38 


\section{DISCLAIMER}

This report was prepared as an account of work sponsored by an agency of the United States Government. Neither the United States Government nor any agency Thereof, nor any of their employees, makes any warranty, express or implied, or assumes any legal liability or responsibility for the accuracy, completeness, or usefulness of any information, apparatus, product, or process disclosed, or represents that its use would not infringe privately owned rights. Reference herein to any specific commercial product, process, or service by trade name, trademark, manufacturer, or otherwise does not necessarily constitute or imply its endorsement, recommendation, or favoring by the United States Government or any agency thereof. The views and opinions of authors expressed herein do not necessarily state or reflect those of the United States Government or any agency thereof. 


\section{DISCLAIMER}

Portions of this document may be illegible in electronic image products. Images are produced from the best available original document. 
The facilities of Argonne National Laboratory are owned by the United States Government. Under the terms of a contract (W-31-109-Eng-38) among the U.S. Department of Energy, Argonne Universities Association and The University of Chicago, the University employs the staff and operates the Laboratory in accordance with policies and programs formulated, approved and reviewed by the Association.

\section{MEMBERS OF ARGONNE UNIVERSITIES ASSOCIATION}

The Univer sity of Arizona Carnegie-Mellon University Case Western Reserve University The University of Chicago University of Cincinnati Illinois Institute of Technology University of Illinois Indiana University The Uniroroity of Iowa Iowa State University
The University of Kansas Kansas State University Loyola University of Chicago Marquette University The University of Michigan Michigan State University University of Minne sota University of Missouri Pus llive sle 1 Un Uive 1 sily University of Notre Dame
The Ohio State University Ohio University

The Pennsylvania State University Purdue University Saint Louis University Southern Illinois University The University of Texas at Austin Washington Univer sity Wayne State University The University of Wisconsin-Madison

\section{NOTICE}

This report was prepared as an account of work sponsored by the United States Government. Neither the United States nor the United States Department of Energy, nor any of their employees, nor any of their contractors, subcontractors, or their employees, makes any warranty, express or implied, or assumes any legal liability or responsibility for the accuracy, completeness or usefulness of any information, apparatus, product or process disclosed, or represents that its use would not infringe privately-owned rights. Mention of commercial products, their manufacturers, or their suppliers in this publication does notimply or connote approval or disapproval of the product by Argonne National Laboratory or the U. S. Department of Energy.

Printed in the United States of America Available from

National Technical Information Service

U. S. Department of Commerce

5285 Port Royal Road

Springfield, Virginia 22161

Price: Printed Copy $\$ 6.00$; Microfiche $\$ 3.00$ 


\title{
ARGONNE NATIONAL LABORATORY 9700 South Cass Avenue Argonne, Illinois 60549
}

\author{
HYCSOS: A CHEMICAL HEAT PUMP AND \\ ENERGY CONVERSION SYSTEM BASED ON \\ METAL HYDRIDES \\ 1979 Status Report \\ by \\ Irving Sheft, Dieter M. Gruen, \\ and George Lamich \\ Chemistry Division
}

April 1979

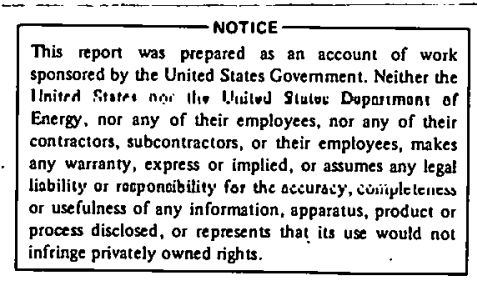

Work supported by the Division of Energy storage Systems U. S. Department of Energy 
THIS PAGE

\section{WAS INTENTIONALLY LEFT BLANK}


TABLE OF CONTENTS

Page

ABSTRACT

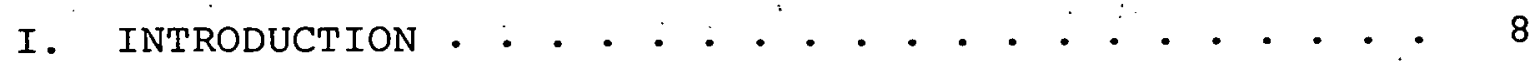

II. HYDRIDE SYSTEMS AS CHEMICAL HEAT PUMPS • • • • . • • 9

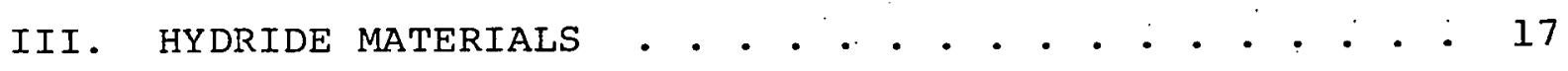

IV. SYSTEM DESIGN DESCRIPTION

A. Heat Transfer Fluid System . . . . . . . . 21

1. Insulation . . . . . . . . . . . . 21

2. Isothermal Installations . . . . . . . . 22

3. New Pumps and Flowmeters.......... 23

B. Hydrogen System . . . . . . . . . . . . 24

1. Hydrogen Recovery and Mass Spectrographic

Analysis . . . . . . . . . . . . . . 24

2. Heat Capacity of Hydride Heat Exchangers (HHE) 25

3. Advanced Design Heat Exchangers . . . . 26

c. The Current HYCSOS System . . . . . . . . 29

D. System Instrumentation . . . . . . . . . . 32

1. Component Description . . . . . . . . 32

a. Data Generation . . . . . . . . 32

1. Temperature . . . . . . . . 32

2. Heat Transfer Fluid Flow . . . . 34

3. Power .......... . . 35

4. Hydrogen Mass Flow . . . . . . 36

5. Pressure . . . . . . . . . 36 
TABLE OF CONTENTS (conta.)

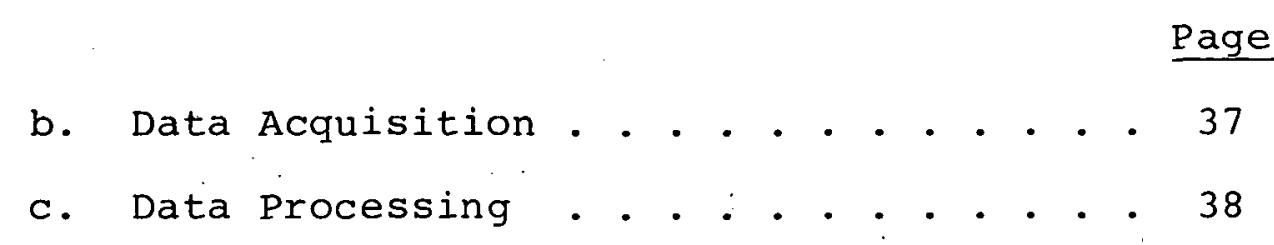

2. Operation.............. 40

V. SYSTEM OPERATION . . . . . . . . . . . . . . . . . . 41
A. System Transient Measurements . . . . . . . 42
B. Simulated Cooling Cycles. . . . . . . . . 46
c. Thermal Conductivity of Hydrides . . . . . . 47

VI, CONCLUSIONS . . . . . . . . . . . . . . . . . . . 50

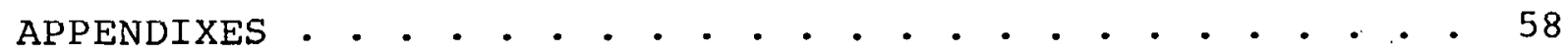

A. Data Logger Channel Functions . . . . . . . b8

B. System Definition and Abbreviations . . . . . 61

C. van't Hoff Vapor Pressure Equations . . . . . 63

REFERENCES . . . . . . . . . . . . . . . . . . . . 64 


\section{LIST OF FIGURES}

No.

Title

Page

1. Thermodynamics of Metal Hydride Chemical Heat Pumps . . 68

2. Plateau Pressure vs Cell Volume for Some Alloy Hydrides. 68

3. Enthalpy Changes in Aluminum Substituted LaNi L $_{5}$ • • . 69

4. Effect of Insulation on the Heat Transfer Fluid System. 69

5. Effect of Heat Transfer Fluid Flow Rate on Hydrogen Transfer . . . . . . . . . . . . . . . 70

6. Advanced Design Aluminum Foam Hydride Heat Exchanger. . 70

7. Construction of Aluminum Foam Heat Exchanger. . . . . 71

8. Construction of Aluminum Foam Heat Exchanger. . . . . 71

9. Hydrogen Absorption on $\mathrm{LaNi}_{5}$-Loaded Aluminum Foam Heat Exchanger. • . . . . . . . . . . . . . . 72

10. Hydrogen System . . . . . . . . . . . . . 73

11. Coiled Tubing Hydride Heat Exchanger . . . . . • . . 73

12. Heat Transfer Fluid System . . . . . . . . . . . . . 74

13. Graphic Control Panel . . . . . . . . . . . . . . 74

14. Performance of Old and New Alloy Beds : . : . : . . : 75

15. Performance of old and New Alloy Beds . . . . . . . . 75

16. Effect of Temperature on Hydrogen Desorption. . • . . 76

17. Effect of Heat Transfer Fluid Flow Rate on Hydrogen Transfer . . . . . . . . . . . . . . 77

18. Comparison of Hydride Bed and Exit Heat Transfer Fluid Temperature . . . . . . . . . . . . . . 78

19. Simulated Cooling Cycle I . . . . . . . . . . . . . 79

20. LaNi 5 Thermal Conductivity . . . . . . . . . . . . . 79 


\section{LIST OF TABLES}

No.

Title

Page

1. Examples of Chemical Heat Pump operating Temperatures . . . . . . . . . . . . . . 16

2. Plateau Pressure and Alloy Cell Volume Data . . . 18

3: Heat Capacity of Coiled Tube Hydride Heat Exchangcrs - . . . . . . . . . . . . 26

4. Time for Half Temperature Recovery . . . . . . . . 45

b. Thermal conductivity of $\mathrm{CaNi}_{5}$ Hydride and $\mathrm{LaNi}_{5}$ Hydride . . . . . . . . . . . . . . . 49

6. HYCSOS Component Sizing and Power Consumption . . . 52

7. Results of HYCSOS Design Optimization . . . . . . 53

8. HYCSOS Component Price Breakdown and Total Price. . 54

9. HYCSOS Design Point Performance . . . . . . . . 56 


\section{HYCSOS: A CHEMICAL HEAT PUMP AND \\ ENERGY CONVERSION SYSTEM BASED ON \\ METAL HYDRIDES}

1979 Status Report

by

Irving Sheft, Dieter M. Gruen, and George Lamich

\section{ABSTRACT}

The current status of the HYCSOS chemical heat pump and energy conversion system based on metal hydrides is described. Heat transfer fluid loops were insulated and modified for isothermal operation.

Software development for HYCSOS manual mode operation was completed. Routines to handle data acquisition, logging, compression, correction and plotting, using a Tektronix Graphics system with flexible disk data storage, provide a rapid and versatile means of presenting HYCSOS data for analysis.

Advanced concept heat exchangers to improve the heat transfer. of the hydride bed with the heat transfer fluid are discussed. Preliminary tests made with a LaNi ${ }_{5}$ loaded aluminum foam test unit showed that heat transfer properties are very markedly improved.

Thermodynamic expressions are applied to the selection of alloys for use in HYCSOS. The substitution of aluminum for nickel in $A_{5}$ type alloys is shown to reduce hysteresis and permits the use of potentially lower cost materials with added flexibility for the optimization of engineering design and performance characteristics of the hydride heat pump system.

Transient thermal. measurements on hydride beds of $\mathrm{CaNi}_{5}$ and LaNi $_{5}$ show no deterioration with cycling. Relatively slow heat transfer between the hydride beds and heat transfer fluid in the coiled tube heat exchangers is indicated by temperature lag of the bed and heat transfer fluid. Improved heat transfer is anticipated with aluminum foam heat exchangers. 


\section{INTRODUCTION}

Application of the "heat pump" concept, the use of heat rejected from a refrigeration system to warm a space at somewhat higher temperature, has been discussed for many years and was first pointed out by Lord Kelvin. (1) Interest in solar energy driven heat pumps, including chemical heat pumps has recently been shown. $(2-4)$

The Argonne HYCSOS system is a two hydride concept ${ }^{(5-8)}$ operating as a chemical heat pump for storage and recovery of thermal energy for heating, cooling, and energy conversion. Low grade thermal energy, as from a solar collector, is used to decompose a metal hydride with the higher free energy of dissociation and the released hydrogen is reabsorbed at an intermediate temperature and stored as a second hydride with a lower free energy of dissociation. The heat of reabsorption of the second hydride at the intermediate temperature can be used for space heating. The heat pump mode of the heating cycle is the use of low temperature outdoor heat to decompose the second hydride and reabsorb the hydrogen at the intermediate temperature as the first hydride. The heat of absorption of the first hydride can now be used for space heating. By rejecting the intermediate temperature heat of hydrogen absorption to the outdoors and withdrawing the low temperature from indoors, the heat pump cycle can be used for space cooling. The Hycsos system also lends itself to conversion of thermal energy into useful shaft work. High pressure hydrogen from the high temperature 
dissociation of a hydride could do work in an expansion engine driving an electric generator before being reabsorbed on another bed of the same hydride at a lower pressure and temperature. The Argonne HYCSOS system. (9) designed and constructed to show the scientific feasibility of the concept and to evaluate system components and materials for use as hydrides has been operational for approximately a year. The scientific feasibility was demonstrated by the rapid cycling of hydrogen between $\mathrm{CaNi}_{5}$ hydride and $\mathrm{LaNi}_{5}$ hydride at experimental conditions approaching design specifications. Optimum operational characteristics for this first pair of hydrides are yet to be determined. Because the unit was designed to be a versatile test facility and does not yet have capability for regenerative heat exchange between hydride beds, thermal efficiency measurements of the cycles would not be meaningful. Since the last report, ${ }^{(9)}$ equipment modifications to increase the usefulness of the facility have been made and will be disçussed.

II, HYDRIDE SYSTEMS AS CHEMICAL HEAT PUMPS

A heat pump is a device which absorbs heat at a low temperature and delivers it at a higher temperature. Mechanical heat pumps generally use a compressor to supply the driving action. A chemical heat pump uses the thermal energy of a reversible chemical equilibrium to pump heat from a low temperature to a higher one. For such a thermally driven heat pump, which could be used for either heating or cooling purposes, the thermal energy need not first be converted to mechanical energy. An additional advantage in the heating mode is the ability to 
also use the driving thermal energy. for heating purposes.

The rapid kinetics of hydrogen absorption and desorption with $\mathrm{AB}_{5}$ alloys, the ability to vary the dissociation pressure by controlling the chemical composition of either the $A$ or $B$ component and the high hydrogen carrying capacity of these alloys make them especially useful for chemical heat pump applications. Alloys can be selected so that low grade heat sources such as solar collectors, automobille heat exhaust, nr reject heat from a power plant could be used to drive hydride heat pumps.

Tlie tredtment $(1 n)$ of the following general heat pump equa-. tions can be applied to any pair of compounds and can be used to determine alloy properties for best heat pump operation at specified temperatures.

Consider a thermally driven heat pump used for heating purposes. A quantity of heat $Q_{h}$ is supplied to the heat pump at a high temperature $T_{h}$, heat $Q_{m}$ is delivered by the heat pump at the intermediate temperature $\mathrm{T}_{\mathrm{m}}$ used for space heating, and heat $Q_{\ell}$ is extracted from a lower temperature $T_{\ell}$. For a reversible process,

$$
Q_{m}=Q_{h}+Q_{\ell}
$$

and

$$
\frac{Q_{m}}{T_{m}}=\frac{Q_{h}}{\mathrm{~T}_{h}}+\frac{\stackrel{Q}{l}_{\ell}}{T_{\ell}} .
$$

An index of the efficiency of such a heat pump, the coefficient 
of the performance*, $\operatorname{COP}_{\mathrm{H}}$, the ratio of the useful heat delivered to the required.high temperature heat imput, can be seen to be

$$
\operatorname{COP}_{\mathrm{H}} \equiv \frac{Q_{\mathrm{m}}}{Q_{\mathrm{h}}}=\frac{\mathrm{T}_{\mathrm{m}}}{\mathrm{T}_{\mathrm{h}}}\left[\frac{\mathrm{T}_{\mathrm{h}}-\mathrm{T}_{\ell}}{\mathrm{T}_{\mathrm{m}}-\mathrm{T}_{\ell}}\right] \text {. }
$$

The coefficient as defined by the ratio. of heats refers to the lowest $\mathrm{T}_{\ell}$ achievable. Higher performances can be reached as the low temperature approaches the intermediate temperature to which the low temperature heat is pumped.

For the specific case where the heat pump consists of a pair of metal hydrides $M_{1}$ and $M_{2}$ with hydrogen flowing freely between them, $M_{2}$ cycles between temperatures $T_{\ell}$ and $T_{m}$ with corresponding dissociation pressures $\mathrm{P}_{1}$ and $\mathrm{P}_{2}$ and $\mathrm{M}_{1}$ cycles between temperatures $T_{m}$ and $T_{h}$ where its dissociation pressures are $\mathrm{P}_{1}$ and $\mathrm{P}_{2}$ respectively. The equilibrium dissociation pressures in the two phase region, which are plotted in Figure 1, are determined by the enthalpies $\Delta \mathrm{H}_{\mathrm{M}_{2}}$ and $\Delta \mathrm{H}_{\mathrm{M}_{1}}$ of the hydride formation reactions and by the entropies $\Delta \mathrm{S}_{\mathrm{M}_{2}}$ and $\Delta \mathrm{S}_{\mathrm{M}_{1}}$.

Not to be contused with coefficient of performance, ${ }^{*} O{ }_{C}$, of refrigeration cycles which is the ratio of the refrigeration effect to the heat input. In terms of notation used here

$$
\operatorname{COP}_{\varsigma} \doteq \frac{Q_{\ell}}{Q_{h}}=\frac{{ }^{\prime} \ell}{T_{h}}\left[\frac{T_{h}-T_{m}}{T_{m}-T_{\ell}}\right] \text {. }
$$


To operate the hydrides $M_{1}$ and $M_{2}$ in the heat pump mode, start with $M_{1}$ saturated with hydrogen at $\mathrm{T}_{\mathrm{m}}$ and $\mathrm{P}_{1}$. Heat $\mathrm{M}_{1}$ to $\mathrm{T}_{\mathrm{h}}$ causing the pressure to rise to $\mathrm{P}_{2}$ and hydrogen to desorb. The released hydrogen is absorbed by $\mathrm{M}_{2}$ at $\mathrm{T}_{\mathrm{m}}$ and $\mathrm{P}_{2}$ ! the heat of absorption $\Delta \mathrm{H}_{\mathrm{M}_{2}}$ being released at $\mathrm{T}_{\mathrm{m}}$. The temperature of $\mathrm{M}_{1}$ is now lowered to $\mathrm{T}_{\mathrm{m}}$ and that of $\mathrm{M}_{2}$ to $\mathrm{T}_{\ell}$. Hydrogen desorbing from $\mathrm{M}_{2}$ at $\mathrm{T}_{\ell}$ absorbs heat from the environment while the heat of reaction, $\Delta \mathrm{H}_{\mathrm{M}_{1}}$, is again released at $\mathrm{T}_{\mathrm{m}} \cdot$. Hydrogen gas is the working fluid in this closed cycle which can be repeated indefinitely.

It is clear that to optimize the choice of metal hydride pairs for a particular mode of heat pump operation, the relationship between the thermodynamic quantities governing the hydride formation reactions and the operating temperatures $T_{h^{\prime}} T_{m}$ and $T_{\ell}$ needs to be established.

Three possibilities are shown in Figure 1 for the relationships between the thermodynamic quantities of $M_{2}$ and $M_{1} \cdot$ They are as follows:

$$
\begin{aligned}
& \text { 1. } \Delta \mathrm{H}_{\mathrm{M}_{2}}<\Delta \mathrm{H}_{\mathrm{M}_{1}} ; \Delta \mathrm{S}_{\mathrm{M}_{2}}>\Delta \mathrm{S}_{\mathrm{M}_{1}} \\
& \text { 2. } \Delta \mathrm{H}_{\mathrm{M}_{2}}<\Delta \mathrm{H}_{\mathrm{M}_{1}} ; \Delta \mathrm{S}_{\mathrm{M}_{2}}=\Delta \mathrm{S}_{\mathrm{M}_{1}} \\
& \text { 3. } \Delta \mathrm{H}_{\mathrm{M}_{2}}=\Delta \mathrm{H}_{\mathrm{M}_{1}} ; \Delta \mathrm{S}_{\mathrm{M}_{2}}>\Delta \mathrm{S}_{\mathrm{M}_{1}}
\end{aligned}
$$

1. For the general case in both heating and cooling cycles, $\Delta \mathrm{H}_{\mathrm{M}_{2}} \neq \Delta \mathrm{H}_{\mathrm{M}_{1}}, \Delta \mathrm{S}_{\mathrm{M}_{2}} \neq \Delta \mathrm{S}_{\mathrm{M}_{1}}$ ', inspection of Figure 1 shows 
that

$$
\begin{gathered}
-\mathrm{R} \ln \mathrm{p}_{2}=\frac{\Delta \mathrm{F}_{\mathrm{M}_{2}}}{\mathrm{I}_{\mathrm{m}}^{\prime}}=\frac{\Delta \mathrm{F}_{\mathrm{M}_{1}}}{\mathrm{~T}_{\mathrm{h}}} . \\
-\mathrm{R} \ln \mathrm{p}_{1}=\frac{\Delta \mathrm{F}_{\mathrm{M}_{2}}}{\mathrm{~T}_{\ell}}=\frac{\Delta \mathrm{F}_{\mathrm{M}_{1}}}{\mathrm{~T}_{\mathrm{m}}} .
\end{gathered}
$$

Straightforward substitution and rearrangement gives

$$
\frac{\Delta \mathrm{H}_{\mathrm{M}_{2}}}{\Delta \mathrm{H}_{\mathrm{M}_{1}}}-\frac{\mathrm{T}_{\mathrm{m}}\left(\Delta \mathrm{S}_{\mathrm{M}_{2}}-\Delta \mathrm{S}_{\mathrm{M}_{1}}\right)}{\Delta \mathrm{H}_{\mathrm{M}_{1}}}=\frac{\mathrm{T}_{\mathrm{m}}}{\mathrm{T}_{\mathrm{h}}}
$$

and

$$
\frac{\Delta \mathrm{H}_{\mathrm{M}_{2}}}{\Delta \mathrm{H}_{\mathrm{M}_{1}}}-\frac{\mathrm{T}_{\ell}\left(\Delta \mathrm{S}_{\mathrm{M}_{2}}-\Delta \mathrm{S}_{\mathrm{M}_{1}}\right)}{\Delta \mathrm{H}_{\mathrm{M}_{1}}}=\frac{\mathrm{T}_{\ell}}{\mathrm{T}_{\mathrm{m}}} .
$$

Since $\Delta \mathrm{H}_{\mathrm{M}_{1}}$ is the high temperature, $\mathrm{T}_{\mathrm{h}}$, heat $\left(\mathrm{Q}_{\mathrm{h}}\right)$ used to drive $\Delta \mathrm{H}_{\mathrm{M}_{2}}\left(\mathrm{Q}_{\ell}\right)$ from the low temperature, $\mathrm{T}_{\ell}$, to $\mathrm{T}_{\mathrm{m}}$, and is itself used for heating at $\mathrm{T}_{\mathrm{m}}$, the heating cycle coefficient of performance of the hydride heat pump is.

$$
\operatorname{COP}_{\mathrm{H}}=\frac{\Delta \mathrm{H}_{\mathrm{M}_{2}}+\Delta \mathrm{H}_{\mathrm{M}_{1}}}{\Delta \mathrm{H}_{\mathrm{M}_{1}}}=1+\frac{\Delta \mathrm{H}_{\mathrm{M}_{2}}}{\Delta \mathrm{H}_{\mathrm{M}_{1}}} .
$$

Combining with equation (1), and (2) shows that, for the general case, the performance of a hydride heat pump in the heating cycle,

$$
\operatorname{COP}_{H}=\frac{T_{m}\left(T_{h}-T_{\ell}\right)}{T_{h}\left(T_{m}-T_{\ell}^{\prime}\right)}
$$

is the same as that for a mechanical heat pump operating reversibly for heating purposes. 
For operation in the cooling cycle where

$$
\mathrm{COP}_{\mathrm{C}}=\frac{\Delta \mathrm{H}_{\mathrm{M}_{2}}}{\Delta \mathrm{H}_{\mathrm{M}_{1}}},
$$

equations (1) and (2) reduce to

$$
\operatorname{COP}_{\mathrm{c}}=\frac{\mathrm{T}_{\ell}}{\mathrm{T}_{\mathrm{h}}}\left(\frac{\mathrm{T}_{\mathrm{h}}-\mathrm{T}_{\mathrm{m}}}{\mathrm{T}_{\mathrm{m}}-\mathrm{T}_{\ell}}\right),
$$

also the same as for a mechanical heat pump.

2. Fur the special case: $\Delta \mathrm{s}_{\mathrm{M}_{2}}=\Delta \mathrm{s}_{\mathrm{M}_{1}}$,

$$
\frac{\Delta \mathrm{H}_{\mathrm{M}_{2}}}{\Delta \mathrm{H}_{\mathrm{M}_{1}}}=\frac{{ }^{\mathrm{I}} \mathrm{m}}{\mathrm{T}_{\mathrm{h}}}=\frac{\mathrm{T}_{\ell}}{\mathrm{T}_{\mathrm{m}}}
$$

from which it follows that

$$
\mathrm{T}_{\mathrm{m}}^{2}=\mathrm{T}_{\mathrm{h}} \mathrm{T}_{\ell} .
$$

In the heating cycle,

$$
\begin{array}{r}
\mathrm{T}_{\mathrm{h}}=\frac{\mathrm{T}_{\mathrm{m}}^{2}}{\mathrm{~T}_{\ell}} \quad \text { and } \\
\operatorname{COP}_{\mathrm{H}}=\frac{\mathrm{T}_{\mathrm{m}}}{\left(\frac{\mathrm{T}_{\mathrm{m}}^{2}}{\mathrm{~T}_{\ell}}\right)}\left[\begin{array}{l}
\frac{\mathrm{T}_{\mathrm{m}}^{2}}{\mathrm{~T}_{\ell}}-\mathrm{T}_{\ell} \\
\mathrm{T}_{\mathrm{m}}^{-\mathrm{T}_{\ell}}
\end{array}\right] .
\end{array}
$$




$$
\begin{aligned}
\operatorname{COP} & \frac{\left(\frac{\mathrm{T}_{\mathrm{m}}^{2}}{\mathrm{~T}_{\ell}}\right)}{\left(\frac{\mathrm{T}_{\mathrm{m}}^{2}}{\mathrm{~T}_{\ell}}\right) \cdot \frac{\mathrm{T}_{\ell}}{\mathrm{T}_{\mathrm{m}}^{2}}} \cdot \frac{\left(\frac{\mathrm{T}_{\ell}}{\mathrm{T}_{\ell}}\right)}{\mathrm{T}_{\mathrm{m}}}-\frac{\mathrm{T}_{\ell}}{\mathrm{T}_{\mathrm{m}}} \cdot \frac{\left(\frac{\mathrm{T}_{\ell}}{\mathrm{T}_{\mathrm{m}}}\right)^{2}}{1-\frac{\mathrm{T}_{\ell}}{\mathrm{T}_{\mathrm{m}}}} \\
\operatorname{COP}_{\mathrm{H}} & =1+\frac{\mathrm{T}_{\ell}}{\mathrm{T}_{\mathrm{m}}} .
\end{aligned}
$$

The performance approaches 2 as $\mathrm{T}_{\ell}$ approaches $\mathrm{T}_{\mathrm{m}}$.

In the cooling cycle for this restricted case,

$$
\operatorname{COP}_{\mathrm{c}}=\frac{\mathrm{H}_{\mathrm{M}_{2}}}{\mathrm{H}_{\mathrm{M}_{1}}}=\frac{\mathrm{T}_{\mathrm{m}}}{\mathrm{T}_{\mathrm{h}}}=\frac{\mathrm{T}_{\ell}}{\mathrm{T}_{\mathrm{m}}}
$$

approaching a maximum of 1 as $\mathrm{T}_{\mathrm{m}}$ approaches $\mathrm{T}_{\mathrm{h}}$ or $\mathrm{T}_{\ell}$.

3. For the special case: $\Delta_{M_{2}}=\Delta \mathrm{H}_{M_{1}}=\Delta \mathrm{H}$

$$
\begin{aligned}
& \frac{\Delta S_{M_{2}}-\Delta S_{M_{1}}}{\Delta H}=\frac{1}{T_{m}}-\frac{1}{T_{h}} \\
& \frac{\Delta S_{M_{2}}-\Delta S_{M_{1}}}{\Delta H}=\frac{1}{T_{\ell}}-\frac{1}{T_{m}}
\end{aligned}
$$

from which it follows that

$$
\frac{\mathrm{T}_{\mathrm{m}}}{\mathrm{T}_{\mathrm{h}}}+\frac{\mathrm{T}_{\mathrm{m}}}{\mathrm{T}_{\ell}}=2
$$

In the heating cycle for this case, $\operatorname{cop}_{\mathrm{H}}=1+\frac{\Delta \mathrm{H}_{\mathrm{M}_{2}}}{\Delta \mathrm{H}_{\mathrm{M}_{1}}}=2$.

In the cooling cycle

$$
\operatorname{COP}_{C}=\frac{\Delta \mathrm{H}_{\mathrm{M}_{2}}}{\Delta \mathrm{H}_{\mathrm{M}_{1}}}=1
$$


One may also use equations (1) and (2) to calculate $\mathrm{T}_{\mathrm{h}}$ and $\mathrm{T}_{. \ell}$ for a range of $\mathrm{T}_{\mathrm{m}}$ in both cycles of hydride heat pump operation if one has available the $\Delta H$ and $\Delta S$ for each of $a$ particular pair of metal hydrides. 'Such calculations have been made for the pair CaNi $_{5}$-hydride $\left(\Delta \mathrm{H}_{\mathrm{M}_{1}}=.31 .6 \mathrm{~kJ} / \mathrm{mole}\right.$, $\left.\Delta \mathrm{S}_{\mathrm{M}_{1}}=100 \mathrm{~J} / \mathrm{mole}\right)$ and LaNi $_{5}$-hydride $\left(\Delta \dot{\mathrm{H}}_{\mathrm{M}_{2}}=30.1 \mathrm{~kJ} / \mathrm{mole}\right.$, $\left.\Delta \mathrm{S}_{\mathrm{M}_{2}}=109 \mathrm{~J} / \mathrm{mole}\right)$. The results are listed in Table $\mathrm{I}$. Aleo ligted in Table $I$ are ealeulations of $\mathrm{T}_{\ell}$ for the special cases $\Delta \mathrm{S}_{\mathrm{M}_{2}}=\Delta \mathrm{S}_{\mathrm{M}_{1}}$ and $\Delta \mathrm{H}_{\mathrm{M}_{2}}=\Delta \mathrm{H}_{\mathrm{M}_{1}}$ using the $\mathrm{T}_{\mathrm{m}}$ and $\mathrm{T}_{\mathrm{h}}$ values of columns 1 and 2 . It can be seen that, as shown graphically in Fig. 1 , for fixed $\mathrm{T}_{\mathrm{m}}$ and $\mathrm{T}_{\mathrm{h}}$ ! the lowest refrigeration temperature, $\mathrm{T}_{\ell}$, in the chemical heat pump mode is reached for the case $\Delta S_{M_{2}}=\Delta S_{M_{1}}$ while the least effective heat pump action arises when $\Delta \mathrm{H}_{\mathrm{M}_{2}}=\Delta \mathrm{H}_{\mathrm{M}_{1}}$.

Table 1. Examples of Chemical Heat Pump Operating Temperatures

Hydride pair involving. $\mathrm{T}_{\mathrm{m}}$ and $\mathrm{T}_{\mathrm{h}}$ values of columns $1 \& 2$

$\mathrm{LaNi}_{5}$ and $\mathrm{CaNi}_{5} \quad \mathrm{~S}_{\mathrm{M}_{1}}=\Delta \mathrm{S}_{\mathrm{M}_{2}} \quad \Delta \mathrm{H}_{\mathrm{M}_{1}}=\Delta \mathrm{H}_{\mathrm{M}_{2}}$

\begin{tabular}{lrrrr}
$\mathrm{T}_{\mathrm{m}}\left({ }^{\circ} \mathrm{C}\right)$ & $\mathrm{T}_{\mathrm{h}}\left({ }^{\circ} \mathrm{C}\right)$ & $\mathrm{T}_{\ell}\left({ }^{\circ} \mathrm{C}\right)$ & $\mathrm{T}_{\ell}\left({ }^{\circ} \mathrm{C}\right)$ & $\mathrm{T}_{\ell}\left({ }^{\circ} \mathrm{C}\right)$ \\
\hline 20 & 64.5 & -15.6 & -18.6 & -14.1 \\
30 & 77.2 & -7.5 & -10.8 & -6.0 \\
40 & 90.0 & +0.5 & -3.1 & +2.1 \\
50 & 102.8 & +8.5 & +4.6 & +10.2 \\
60 & 115.8 & +16.4 & +12.2 & +18.2
\end{tabular}


III. HYDRIDE MATERIALS

The selection and availablility of desirable pairs of hydrides are important to the efficient and economical operation of HYCSOS, as seen from the heat pump relations developed in section II. The optimum hydride properties depend on the operating temperature regime and so particular pairs could well vary with geographic location. Although a theoretical understanding sufficient to predict dissociation pressures of metal hydrides does not yet exist, a number of attempts to correlate dissociation pressure empirically with other parameters have been made with some degree of success.

The importance of geometric factors in determining the stability of transition metal hydrides has been known for some time. The additional importance of crystal structure to the affinity of metals for hydrogen and the stability of the resulting hydride has been reported. (12-14) Among sets of hydrogen absorbing alloys having the same crystal structure, the thermal stability of the hydride (or logarithm of dissociation pressure) correlates well with the size of the tetrahedral holes in the metal lattice. These considerations led to a direct correlation ${ }^{(15)}$ between the crystal cell volume of the alloy and the plateau dissociation pressure. Figure 2 shows a linear plot ${ }^{(16)}$ of the logarithm of the plateau dissociation pressure vs. cell volume for alloy material collected in Table II.

Another approach ${ }^{(23-27)}$ to predicting the dissociation pressures of ternary alloy hydrides is the rule of reversed stability: "when considering a series of intermetallic compounds containing a given hydrogen attracting element (say La) it appears 
TABLE 2

Plateau Pressure and Alloy Cell Volume Data

Number

Compound

$P_{\text {eq }}\left(\right.$ at $\left.20^{\circ}\right)(\mathrm{atm})$

Reference

Cell Vol. $\left(\AA^{3}\right)$

1

1

$\mathrm{LaCO}_{5}$

0.04

17,18

89.74

$2 \mathrm{CeCO}_{5}$

I. 55

18

84.30

$3 \quad \mathrm{PrCO}_{5}$

0.51

18

87.13

$4 \mathrm{NdCO}_{5}$

0.68

18

86.79

$5 \mathrm{SmCO}_{5}$

3.30

18

85.67

6

$\mathrm{GdCO}_{5}$

24

18

85.19

7 vris

17. . $^{\mathrm{a}}$

1.9

83.96

8

9

$\mathrm{LaNi}_{5}$

$1.5^{\mathrm{a}}$

20

86.54

$9 \quad \operatorname{PrNi}_{5}$

$8^{b}$

21

$84.7 \cdot 3$

10

$\mathrm{SmNi}_{5}$

$30^{\mathrm{b}}$

21

83.44

$11 \quad \mathrm{GdNi}_{5}$

$120^{\mathrm{b}}$

21

82.58

12

$\operatorname{Lacio}_{4} \mathrm{Ni}$

$0.055^{r}$

22

89.01

13

$\operatorname{LaCo}_{3} \mathrm{Ni}_{2}$

$0.12^{\mathrm{C}}$

22

88.44

14

$\mathrm{LaCO}_{2} \mathrm{Ni}_{3}$

$0.22^{-1}$

22

87.80

15

$\mathrm{NdNi}_{5}$

$12.7^{\mathbf{a}}$

15

84.32

16

$\mathrm{LaNi}_{4} .0^{\mathrm{Al}} 0.2$

$0.57^{\mathrm{a}}$

16

87.28

17

LaNi $_{4.6^{\mathrm{Al}} 0.4}$

$0.22^{a}$

16

88.24

18

$\mathrm{LaNi}_{4} \mathrm{AL}$

0.005

16

90.51

${ }^{a}$ Calculated from given data or equation.

${ }^{b}$ Given at $23^{\circ}$ only.

CEstimated from data at $40^{\circ}$ 
that the lower the stability of this.compound, the higher its. tendency to absorb hydrogen." (27) In the two phase: plateau region, the dissociation pressure can be approximated by the van't Hoff equation

$$
\text { ln } \mathrm{P}_{\text {eq }}=\Delta \mathrm{H} / \mathrm{RT}-\Delta \mathrm{S} / \mathrm{R}
$$

where $\Delta \mathrm{S}$ and $\Delta \mathrm{H}$ are the entropy and enthalpy changes per mole $\mathrm{H}_{2}$ for the hydriding reaction. Since the entropy is assumed to be close to the high entropy of gaseous $\mathrm{H}_{2}$ ( $31 \mathrm{cal} /\left(\right.$ deg mole $\left.\mathrm{H}_{2}\right)$ ), and approximately constant, the dissociation pressure is predominantly determined by enthalpy changes. The heat of formation of the ternary hydride, $\triangle H\left(A B{ }_{n}{ }^{H} 2 m\right)$ is said to be composed of three terms:

$$
\Delta \mathrm{H}\left(\mathrm{AB}_{\mathrm{n}} \mathrm{H}_{2 \mathrm{~m}}\right)=\Delta \mathrm{H}\left(\mathrm{AH}_{\mathrm{m}}\right)+\Delta \mathrm{H}\left(\mathrm{B}_{\mathrm{n}} \mathrm{H}_{\mathrm{m}}\right)-\Delta \mathrm{H}\left(\mathrm{AB}_{\mathrm{n}}\right) .
$$

The heats of formation of many binary hydrides have been determined experimentally and a simple model $(24,28)$ involving contact interaction between first neighbor atomic cells is used to calculate the heat of formation of the compound $\triangle H\left(A B_{n}\right)$.

Although the rule of reversed stability may be useful in the limited sense of indicating an order of stability in a series containing the. same hydrogen alliacting element, it proved unreliable for calculating plateau pressures. Using calculated values for $\triangle \mathrm{H}\left(\mathrm{AB}_{\mathrm{n}} \mathrm{H}_{2 \mathrm{~m}}\right)$ combined with "reasonably good estimated entropies" in the van't Hoff equation, Steward, Lakner and Uribe (29). obtained calculated plateau pressures for some ternary hydrides that were lower than experimentally determined values by 6 to 23 orders of magnitude and concluded the error must lie in the calculated enthalpies for the intermetaliic compounds and that the present 
level of sophistication given by the empirical formulae does not allow reasonable accuracies in calculating ternary hydride stabilities in terms of their plateau pressures.

The use of limited correlations has been useful in obtaining hydrides with specified properties. Although varying the ratio of nickel to lanthanum in $\mathrm{LaNi}_{5}$, partially substituting other lanthanides for lanthanum or other transition metals for nickel liave been lnown $(12,23)$ for some time to rhange the plateau dissociation pressure by a factor of about 4 , there has been no systematic way of changing the enthalpies of hydriding reactions over a wide range. It has recently been shown $(16,30,31)$ that aluminum substitutions for nickel, forming the $\operatorname{LaNi}_{5-\mathrm{x}} \mathrm{Al}_{\mathrm{x}}$ ternary alloy system, lowers the plateau pressure by a factor of about $10^{3}$ in going from $\mathrm{LaNi}_{5}$ to $\mathrm{LaNi}_{4} \mathrm{Al}$. Measurements on well annealed samples in the LaNi. $5-x^{A}{ }_{x}$ system show the entropy chanyes over a wide composition range to be virtually constant. (32)

Also, a linear relationship has been observed between the aluminum content and the heat of formation for the hydriding reaction. Within experimental errur, a 0.1 change in " $x$ ", the aluminum content, changes the heat of formation by about $0.5 \mathrm{kcal} / \mathrm{molH}_{2}{ }^{(33)}$ This relation is shown in Figure 3. Aluminum has also been substituted for nickel in mishmetal * (Mm) pentanickel

\footnotetext{
"Mishmetal is the unrefined rare earth mixture of average composition; 48-50\% $\mathrm{Ce}, 32-34 \% \mathrm{La}, 13-14 \% \mathrm{Nd}, 4-5 \%$ Pr and 1-2\% other rare earth.
} 
alloy with similar reduction in plateau dissociation pressure.

A substantial additional benefit.is the reduction in the impractical high hysteresis in the unsubstituted alloy. The use of low cost mishmetal results in alloy raw material costs $35-45 \%$ that of present LaNi ${ }_{5}$ costs and about $70 \%$ of future costs on a per unit hydrogen storage basis. The advent of these ternary alloys adds flexibility to the selection of alloy pairs for the optimization of engineering design and performance characteristics of the hydride heat pump system.

\section{SYSTEM DESIGN DESCRIPTION}

The system as originally constructed has already been described. (9) A number of modifications in design dictated by operational experience have been incorporated. The current system, including operating characteristics and measured properties, will be described.

\section{A. Heat Transfer Fluid System}

1. Insulation

To improve the reliability of thermal measurements, heat transfer with the ambient was reduced by insulating the heat transfer fluid loops with a double layer of fiberglass wrap insulation. The heater sections and hydride heat exchangers (HHE). were insulated with rigid l" fiberglass insulation. Figure 4 shows the effect of pump frictional heat input on loop $C$ and HHE- 4 with and without insulation. After 2 hours, while the uninsulated system at $45^{\circ} \mathrm{C}$ was losing as much heat as the pump was adding, the insulated system at $62^{\circ}$ was still increasing 
in temperature at about $7^{\circ} \mathrm{C} / \mathrm{hr}$.

\section{Isothermal Installations}

For the measurements made with the HYCSOS system to be more indicative of the manner in which such a system would be used, the heat transfer fluid system was modified to permit each loop to be used isothermally.

Loop A, the primary thermal energy input with $18 \mathrm{kw}$ electric heat, was already operating isothermally and was not changed.

Loop B, including a building water cooled (loop W) heat exchanger of $25 \mathrm{kw}$ heat transfer capacity representing the space being heated in the heating cycle and serving for the ambient heat rejection during the cooling cycles, was modified to include a temperature modulating valve, Sterlco Model \#R-150-F with an operating range $29^{\circ} \mathrm{C}-51^{\circ} \mathrm{C}$, in the discharge leg of the cooling loop $W$. The thermostat bulb sensor was located in the loop $B$ outlet leg of the heat exchanger. A $1 \mathrm{kw}$ heater, regulated by a constant power controller, was place in the loop B inlet leg of the heat exchanger. Heat is removed at constant temperature by varying the flow in cooling loop $W$.

Loop $C$, the refrigeration heat load in the cooling cycle and the ambient heat supply during the heat pump heating cycle, has a $6 \mathrm{kw}$ electric heater in a 1 1/8" copper tube. For isothermal operation a double walled copper tube heat exchanger is used with chilled ethylene glycol-water. in the outer jacket and the heater and loop fluid still in the inner tube. A Haskris 
Model R075 Chiller with a $3 / 4$ hp condensing unit and 2200 $\mathrm{BTU} / \mathrm{hr}$ water to water heat removal capacity at $\sim 20^{\circ} \mathrm{C}$ provides the cooling. Heat could be extracted at an appropriate low temperature by varying the heat input to the loop.

The water in all the heat transfer loops was replaced with a 50 volume percent ethylene glycol-water solution.

\section{New Pumps and Flowmeters.}

The original $0.5 \mathrm{hp}$ heat transfer fluid pumps were sized to design goal cycle response times. The power generation mode, with the shortest cycle time, set the pump size. Hydrogen transfer rates in simulated heating and cooling mode experiments were not significantly affected by fluid flow rates. Figure 5 shows the effect, of fluid flow rates between $51 / \mathrm{min}$ and $12 \mathrm{l} / \mathrm{m}$ on instantaneous and integrated hydrogen transfer. The differences in the instantaneous hydrogen flow rates are generally within flowmeter limits. Small differences are commulative and carried forward in the integrated flow measurements. Since the power generation mode, where the larger pumps were required, has assumed a lower priority and since fluid friction heating and the limited flow variation made these $0.5 \mathrm{hp}$ pumps unnecessary and less, suitable, they were replaced by 60 watt Centrifugal Micropumps, Model 10-41-316, with a continuously variable flow up to about $121 / \mathrm{m}$ for the ethylene glycol fluid at $100^{\circ} \mathrm{C}$. The smaller pumps simplify low temperature isothermal operation of the fluid loops and their reduced power consumption make for greater efficiency. 
Flow Technology Model FT-8 flowmeters with a normal flow range of 3.8 to $38 \mathrm{1} / \mathrm{m}$ and calibrated down to $0.951 / \mathrm{m}$ replaced the older higher range meters to achieve greater accuracy at the lower flow rates. The meters are described in greater detail in Section IV-D.

\section{B. Hydrogen System}

1. Hydrogen Recovery and Mass Spectrographic Analysis. After approximately four months of operation and ten complete cycles, the 37.19 moles of hydrogen (Matheson ultra high purity, 99.999\%) initially charged into one CaNi ${ }_{5}$ and one LaNi $_{5}$ pair of. heat exchangers was removed and analyzed mass spectrochemically. A sample was taken from both the $\mathrm{CaNi}_{5}$ bed and from the LaNi bed. Both samples were greater than 99.9\% $\mathrm{H}_{2}$ with $0.01-0.02 \%$ nitrogen impurity: The gas from each bed was expanded into a known volume. Pressure and temperature were measured and the gas then pumped out. This was repeated sequentially until the pressure, with the alloy bed at $100^{\circ} \mathrm{C}$, was less than 0.1 atm. Based on the pressure-composition diagrams for the two alloys, the residual composition of the $\mathrm{CaNi}_{5}$ was assumed to be $\mathrm{CaNi}_{5} \mathrm{H}_{0.55}$ holding 4.77 moles $\mathrm{H}_{2}$ and the $\operatorname{LaNi}_{5}$ to be $\operatorname{LaNi}_{5} \mathrm{H}_{0.04}$ holding 0.23 moles $\mathrm{H}_{2}$. The total amount of hydrogen recovered, including the residual corrections, was 37.55 moles or 1018 of the amount originally put in. New hydrogen, 37.20 moles, was added to the HHE-2 $\left(\mathrm{CaNi}_{5}\right)$ - HHE-3 $\left(\mathrm{LaNi}_{5}\right)$ loop. 
Hydride heat exchanger 1 and HHE-4 were filled with the same amounts of alloy as in HHE-2 and HHE-3, HHE-1 with $5786 \mathrm{gm}$, 17.344 mole, of $\mathrm{CaNi}_{5}$ and $\mathrm{HHE}-4$ with $5004 \mathrm{gm}, 11.561$ mole, of LaNi $_{5}$. Purified hydrogen, 37.20 moles, was added to this loop and the alloys activated. Hydrogen transfer characteristics of the old and new alloys are reported in section $V$.

2. Heat capacity of Hydride Heat Exchangers (HHE). To better evaluate the thermodynamic operation of the HYCSOS system and reduce the effect of the piping and heat transfer fluid in the system beyond the hydride heat exchangers (HHE) in lowering system efficiency, the heat capacity of the HHE including the contained alloy and heat transfer fluid was determined.

In a calorimetric measurement the temperature rise caused by the absorption in the center of the plateau region of approximately 5 moles of hydrogen on the alloy, i.e., 30-40 kcal, was measured. A copper constantan thermocouple was strapped to the outside of the $\mathrm{HHE}$ and temperature recorded on the digital data logger. Readings were taken every eight seconds during the several minute addition of hydrogen and every five minutes during the temperature drift toward ambient. With two inches rigid plus two inches fiberglass insulation around the HHE, the temperature drift was about $1.5^{\circ} \mathrm{C} / \mathrm{hr}$. By extrapolation of the drift back to the center point of hydrogen addition, the temperature rise due to hydrogen absorption, was determined. The determined heat capacity using accepted heats of absorption is shown in Table 3 
for a $\mathrm{LaNi}_{5}$ and $\mathrm{CaNi}_{5}$ containing heat exchanger.

Table 3 .

Heat Capacity of Coiled Tube Hydride Heat Exchangers

\begin{tabular}{|c|c|c|c|c|c|c|}
\hline $\mathrm{HHE}^{*}$ & $\begin{array}{ll}\text { MOLES } & \mathrm{H}_{2} \\
\text { Added } & \\
\end{array}$ & $\begin{array}{l}\text { Alloy Comp. } \\
\text { Range }\end{array}$ & $\begin{array}{r}\text { Temp } \\
\text { Initial } \\
\end{array}$ & ${ }^{\circ} \mathrm{C}$ & $\begin{array}{c}\Delta \mathrm{H}_{\mathrm{abs}} \\
\mathrm{kcal} / \mathrm{mole}\end{array}$ & $\begin{array}{c}\text { Heat } \\
\text { Capacity } \\
\text { kcal } /{ }^{\circ} \mathrm{C}\end{array}$ \\
\hline 3 & 4.90 & $\operatorname{LaNi}_{5}{ }^{\mathrm{H}} 1.75^{-\mathrm{LaNi}_{5}} 5^{\mathrm{H}} \cdot 2.52$ & 19.0 & 35.4 & 7.2 & 2.15 \\
\hline 3 & 4.92 & $\operatorname{LaNi}_{5}{ }^{\mathrm{H}} 2.59^{-\mathrm{LaNi}_{5} \mathrm{H}_{3}} .36$ & 17.6 & 34.5 & 7.2 & 2.10 \\
\hline 2 & 5.66 & $\mathrm{CaNi}_{5}{ }^{\mathrm{H}} 1.43^{-\mathrm{LaNi}_{5} \mathrm{H}_{2}} 2.07$ & 19.1 & 39.5 & 7.5 & 2.08 \\
\hline 2 & 6.43 & $\mathrm{CaNi}_{5} \mathrm{H}_{2.08} .^{-\mathrm{CaNi}_{5} \mathrm{H}_{2}} .81$ & 18.0 & 41.2 & 7.5 & 2.08 \\
\hline
\end{tabular}

*Hydride Heat Exchanger

For comparison, a value for the heat capacity was calculated from the blueprint dimensions for the volume of contained heat transfer fluid (water, specific heat $=1$ ) and the weight of metal in the heat exchanger from $15 / 8$ " of hydrogen inlet tube to the thermocouple: location in the heat transfer fluid inlet and outlet tubes. A Dulong and Petit value of $6.2 \mathrm{cal} /{ }^{\circ} \mathrm{C}$ was used for the atomic heat capacity of the metal. A heat capacity (35) of 155.00 joule $\mathrm{dog}^{-1} \mathrm{~mole}^{-1}$ (37.02 cal dey ${ }^{-1}$ mole ${ }^{-1}$ ) was uséd tor LaNi 5 and for $\mathrm{CaNi}_{5}$ a value of $37.16 \mathrm{cal} \mathrm{deg}^{-1}$ mole $\mathrm{c}^{-1}$ was calculated from the atomic heat of. $6.2 \mathrm{cal} / \mathrm{deg}$. A heat capacity of $1.88 \mathrm{kcal} / \mathrm{deg}$ was calculated for $H H E-3$ and $2.08 \mathrm{kcal} / \mathrm{deg}$ for $\mathrm{HHE}-2$.

\section{Advanced Design Heat Exchangers.}

The relatively high cost of the alloy hydrides makes rapid cycling necessary in order to achieve economic use of the alloys. The intrinsic reaction rate of the alloys with hydrogen is believed to be very rapid and observed reactions to be heat transfer 
limited, i.e., rates are determined by the rate at which heat of reaction can be removed from or added to the alloy bed. Because of poor particle contact, the thermal conductivity of LaNi $_{5}$ is low. At a void fraction of 0.4 , typical for $\mathrm{LaNi}_{5}$ powder, the thermal conductivity is $0.27 \mathrm{BTU} /\left(\mathrm{hr} . \mathrm{ft} .{ }^{\circ} \mathrm{F}\right),(36)$ only 3\% that of stainless steel. (see also section $V$ for measured thermal conductivity in HYCSOS $\mathrm{LaNi}_{5}$ beds and evidence that the slow step in heat transfer of the hydriding reaction is going from the alloy bed to the first wall.)

Under contract to the Argonne National Laboratory, Energy Research and Generation,"Inc., Oakland, California is designing and fabricating a high performance heat exchanger which can replace and be compared with a current Hycsos hydride heat exchanger. The LaNi $_{5}$ powder is poured into the interstices of a reticulated open-cell aluminum foam that will provide enhanced heat transfer between the hydride powder and the heat transfer fluid. The foam is $93 \%$ void with approximately 20 pore to the inch. The reduced half thickness of the hydride bed, from 0.12 " to $0.02 "$, should. significantly increase the heat transfer rate. (See section V A). A stack of six foam matrices is brazed to aluminum sheets which form the fluid flow channels. The flow channels merge to form integral headers that connect to the external plumbing. One micron porous 316 stainless steel sheet is brazed around the alloy containing foam lo retain the powder and provide for hydrogen 
access to the alloy. Two such six-high stacks are installed in a pressure vessel which contains access for hydrogen. A perspective drawing is shown in Figure 6.

A three-high stack test module containing $1030 \mathrm{gm} \mathrm{LaNi}_{5}$, Figures 7 and 8 , has been received for preliminary examination. The alloy was readily hydrided and dehydrided several times. In a single adiabatic experiment, 1.74 moles $\mathrm{H}_{2}$ were desorbed. Figure 9 shows the subsequent rapid adiabatic absorption of 1.07 moles $\mathrm{H}_{2}$. Equilibrium absorption pressure is reached in approximately $30^{\circ}$ seconds showing the temperature of the unit to be uniform. The pressure rise after 10 minutes is due to absorption of ambient heat and the resulting temperature increase of the alloy bed.

Another scheme ${ }^{(37)}$ to improve heat transfer characteristics of metal hydrides is to make compactions with a metal powder, i.e. , $\mathrm{Cu}, \mathrm{Ni}$ or $\mathrm{Al}$, having a much larger thermal conductivity than the hydride. Calculations show ${ }^{(37)}$ a three-fold increase in heat transfer rate for a compaction over a powder bed. Metal hydride electrodes for electrochemical storage have been prepared with an excess of fine copper or carbonyl-nickel powder and coldpressing the mixture. These electrodes have been hydrogen cycled without disintegration. In connection with the use of hydrogen in motor vehicles, Daimler-Benz AG reported $(39)$ the preparation of hollow cylinders $10-20 \mathrm{~cm}$ long, $36 \mathrm{~mm}$ OD and $8 \mathrm{~mm}$ ID; the alloy powder is mixed with. $7.5 \%$ fine aluminum powder and hot pressed at 
$500-600^{\circ} \mathrm{C}$. The thermal conductivity is 10-20 times better than the alloy powder, approaching that of sintered aluminum.

\section{The current HYCSOS System}

The Argonne HYCSOS system is a demonstration test facility to evaluate materials and components for use in the hydride heat pump concept. In this dual metal-metal hydride concept, hydrogen gas is transferred from heat exchangers containing a metal hydride bed of one composition to heat exchangers containing a metal hydride bed of another composition by the action of applied thermal energy. The heat of formation of one type of hydride compound (termed MI hydride) and sensible heats associated with system heat capacities will be supplied, at a:specific temperature level which is commensurate with required system hydrogen pressure level, to decompose the Ml hydride and drive the hydrogen to the other metal (termed M2) system where the hydrogen is absorbed.

The dual metal-metal hydride demonstration unit consists of four heat exchangers (HHE) of approximately one-half gallon volumetric capacity each, containing two different types of metal powders or metal hydride powders. (See Figure 10.) The hydride heat exchangers and hydrogen piping system are made of 316 type stainless steel. For the heat storage and refrigeration tests, two of the heat exchangers contain lanthanum-nickel and/or its hydride, the other two contain calcium nickel and/or its hydride. For the power generation tests, only three heat exchangers are 
used containing either lanthanum-nickel or calcium-nickel. Two hydride heat exchangers, HHE-1 and HHE-2 contain 17.334 moles $\mathrm{CaNi}_{5}$ each and two, HHE-3 and HHE-4, contain 11.561 mole LaNi $_{5}$ each. A hydrogen filter, one micron retention, is incorporated immediately above the hydride heat exchangers to preclude transfer of hydride powder through the lines and to prevent contamination of other hydride material.

Inlerhäl liéal liansfer surfaces in the form of coiled tubing, are provided in each of the hydride beds (Figure ll) with the heat transfer cooling or heating fluid circulating inside the tubing. The alloy powder is between the loops of the coils such that no powder is more than $1 / 8$ inch from a coil surface. Safety relief valves, filters, flowmeters, shutoff valves, and manifolds between the hydride beds are provided in the hydrogen process system. The heat transfer fluid (50\% water-50\% ethylene glycol) is heated electrically $(18 \mathrm{kw})$ in this demonstration system, with automatic variable power input controls, to simulate a solar heat source. Tap water is used as the heat sink in a $25 \mathrm{kw}$ heat exchanger system. Presșures, temperatures and flowrates are measured remotely, monitored and recorded using a digital data acquisition system.

The sizc of the tcst facility was chosen ae a compromise to permit large enough flow rates within the process fluids so standard flowmeters are used, and pumping and heating power 
requirements are met from available laboratory supplies. Heat losses are kept to a minimum with proper insulation and by keeping heat transfer fluid volumes to a minimum. For personnel safety considerations, the hydride containers are surrounded by a well ventilated hood through which a large volume flowrate of air (2000 CFM) is drawn and exhausted outdoors. Continuous hydrogen concentration monitoring, with an alarm set below the flammability limit, is provided to warn of potential danger. Three heat transfer fluid loops, Figure 12, are available and can be remotely. valved and pumped to the appropriate containers. The solar or other suitable low temperature thermal energy input, loop A, is simulated by an $18 \mathrm{kw}$ electric heater. Loop $\mathrm{B}$, including a water cooled heat exchanger of $25 \mathrm{kw}$ heat transfer capacity, represents the space being heated in winter and serves for ambient heat rejection during cooling cycles. A heat exchanger cooling water circuit is provided from the building water supply. A third fluid loop, loop C, with a $6 \mathrm{kw}$ electric heater and water chiller is the refrigeration heat load in the cooling cycle and the ambient heat supply during the recovery cycle.

Information from the various sensors, e.g., temperature, pressure, flow and power is digitized and transmitted by a data logger to a Tektronix data handling system. Important variables are also displayed on the remote graphic panel, Figure 13, from 
which the system is controlled. A detailed description of the controls, instrumentation, and data handling and generation is in Section IV D.

\section{System Instrumentation}

The overall objective for the design of the instrumentation system for HYCSOS was fourfold: 1) provide real-time indication of important system characteristics, 2) provide for logging of data generated during system operation, 3) provide a means of processing raw data, and 4) provide a way to automatically control HYCSOS system operation. The first three segments of the design objective have been met, while the fourth, automatic operation, is in the equipment procurement and development stage. 1. Component Description.

The components of the HYCSOS instrumentation system can be divided by function into three catagories: data generation, data acquisition, and data processing.

a. Látá Generation

1. Temperature

Temperature is sensed with copper-constantan (type $T$ ) ungrounded junction thermocouples. The thermocouple assemblies consist of $1 / 8$ " dia. $31.6 \mathrm{~s} . \mathrm{s}$, sheath over ceramic oxide insulation, with $3 / 4 "$ of the tip end reduced to 1/16" dia. A type $n$ connector is mounted to its free end. Standard type T shielded extension cable is used to connect the thermocouple assembly to the temperature measuring equipment. of thirty-two thermocouples 
used, twenty-six are for temperature recording, four are for graphic panel heat transfer fluid temperature indication, and two are used for loops $A$ and $C$ temperature control.

Control of loops $A$ and $C$ fluid temperature is accomplished through the use of two Leeds and Northrup series 6430 "Electromax III" solid state controllers. These controllers are configured for use with thermocouple input to produce an output current of 0-5 ma d.c. which is proportional to process temperature deviation from setpoint. An alternate mode of operation permits setting a fixed output current within the range, which enables operation of the heater at a constant power level. Each output signal current is then fed to a Robican Corp. series 413.SCR power controllex $(208 \mathrm{v} 3 \varnothing 27.6 \mathrm{kva}$ for heater A, $208 \mathrm{v} 3 \emptyset 10.8 \mathrm{kva}$ for heater $C$ ) which in turn feeds.208 v $3 \varnothing$ time proportioned current to its respective heater. The power controllers are zero voltage firing to minimize line transients and radio frequency interference which might affect other instrument operation. Three safety features have been incorporated into the control circuitry for heaters $A$ and $C$. To prevent inadvertant operation of a heater, each heater contactor coil and "start". switch receives power from its corresponding fluid pump contactor; i.e., the pump must be energized before the heater can be energized. A flow switch, wired in series with each heater contactor "stop" switch, deenergizes the heater in the event of loss of fluid or flow. Finally, a Love Controls Corp. model 48 on/off controller/ 
indicator, also wired in series with each heater contactor "stop" switch, will deenergize its heater in the event of fluid temperature rise beyond the value set on its setpoint selector. These devices also serve as graphic panel indicators for their respective heater outlet temperatures.

The $1 \mathrm{kw}$ heater in loop $\mathrm{B}$ is fed from a Watlow model 52-00-01 percentage power controller. This device permits selection if lie portion $(0.1008)$ of rated powor to be applied to the heater. It is, like the power controllers for heaters $A$ and $C$, a zero voltage firing controller.

Temperatures of loops $B$ and $W$, measured at their respective heat exchanger outlets, are presented on the graphic panel by two Love Controls Corp. model 100 temperature indicators.

2. Heat Transfer Fluid Flow

Heat transfer fluid (HTF) flow rate through the hydride tanks is measured in the fluid inlet line of each tank with a Flow Technology, Inc, model FT-8N2.5LJ graphite journal turbine flowmeter. One additional flowmeter of the same type is used to measure loop $\mathrm{W}$ flow rate through heat exchanger $\mathrm{HXB}$. The flowmeters produce self-generated $a-c$ current outputs that are fed to individual Sensotec, Inc. model FD-7 signal conditioners which have been modified to be compatible with the output characteristics of the FT-8 flowmeters. The signal conditioner circuits in turn. convert the flowmeter a-c signal to a d-c voltage between 0 and $10 \mathrm{v}$ which is linearly proportional to input signall 
frequency. The signal conditioners provide zero offset and gain controls, the latter a convenience in providing an integral voltage/frequency relationship to the output. The signals are then routed to Control Products Div. (Bell \& Howell Co.) model 20-320 dual potentiometer/amplifier modules where they are scaled to convenient engineering units for logging and graphic panel indicators.

\section{Power}

The power consumed by the HTF pumps and loops $A$ and $C$ heaters is individually measured with ohio semitronics, Inc. model PC-5 power transducers. These units produce a $0-10 \mathrm{~V} d-c$ output which is proportional to instantaneous power through the circuit. The output signal of each transducer is fed through a scaling potentiometer to a Control products Div. model 19407A dýnamic response module configured as an integrator. The. integrator outputs are voltages $(0-10 \mathrm{v} d-c)$ which represent the total power consumed by each heater or motor with time. This information is logged but not displayed.

In the case of heaters $A$ and $C$, the power transducer output is also fed through separate Control Products Division model 19-422 adjustable lag modules to individual heater power demand indicators on the graphic panel. The lag modules are configured as low pass filters and are used to provide smoothing of the highly intermittant power transducer signals before they are applied to the power demand indicators. 


\section{Hydrogen Mass Flow}

The mass flow rate of hydrogen leaving each HHE is sensed in the line between the $H H E$ and its associated manifold valve by a Brooks Instrument Division (Emerson Electric Co.) model 5812 thermal mass flowmeter. Each flowmeter output signal $(0-5 \mathrm{v} d-\mathrm{c})$ is amplified by one half of a control Products Division model 20-320 dual potentiometer/amplifier module which is set to scale the mass flow rate signal in grams $\mathrm{H}_{2} / \mathrm{min}$. This gain element output signal is used for logging the mass flow rate and is also applied through a voltage divider/range selector switch combination to a mass flow rate indicator on the graphic panel. Integrated mass flow information is obtained by feeding the mass flow rate signal from the gain element through a scaling potentionmeter to a Control Products Division model 19-407. A dynamic response module, configured as an integrator; which provides a suitably scaled integrated mass flow signal for logging and graphic panel indicators.

\section{Prossurc}

Hydrogen pressure is sensed in the line above each HHE by Sensotec, Inc. model TJE bonded strain gage pressure transducers. Excitation for the strain gage bridge and conditioning of the bridge output signal is provided by separate Sensotec, Inc. model SCA-7 signal conditioner amplifiers. The output of each signal conditioner is a scaled d-c voltage (100 psia/v) which is available for logging and graphic panel pressure indicators. 
HTF static preload and pump outlet pressure indication is provided locally by standard Bourdon tube gages.

\section{b. Data Acquisition}

The system requirement for data logging, data processing and, eventually, system control dictated the need for a convenient, automatic means of converting analog data (thermocouple and transducer outputs) to digital data, recording the data, and transmitting the data to a data processor/system controller. This need was met by a Fluke Mfg. Co., Inc. model $2240 \mathrm{~B}$ programmable data logger which, by the incorporation of various optional circuit boards into the mainframe, provided the required capabilities. The configuration of our instrument includes thirty analog voltage and thirty thermocouple input channels, the temperature measurement section providing linearization and scaling of the thermocouple signals to produce temperature readout in degrees celsius. Up to fifteen positive or negative values can be designated as high or low limits and applied to. individual measurement channels to provide "out of limit" alarm indication.

All data logger functions, i.e., channel selection, limit designation, scan mode (interval, single, or continuous), scan interval, time, run identification, start, and stop, can be programmed or selected either from the $2240 \mathrm{~B}$ front panel or remotely by the computer. Communication with the data processing equipment is via an RS-232C full duplex data communications interface 
at a data rate of 2400 baud. A paper tape printer is built into the $2240 \mathrm{~B}$ and provides hardcopy of measurement data and program listing when the data logger is operated under local control, but is not available during remote mode operation. An LED display on the $2240 \mathrm{~B}$ front panel also provides measurement data, time, and "out of limit' indication as well as verification of program input data during programming.

\section{c. Data Processing}

The instrumentation system described up to this point represents a minimal data gathering and logging arrangement. Two interdependent limitations on system performance are imposed by such an arrangement; i.e., low measurement rate and large data volume. The $2240 \mathrm{~B}$ data logger, although capable of a measurement rate of approximately 12 channels/sec., is slowed to $<2.5$ channels/sec. by the paper tape printer which limits the ability of the system to resolve fast process transients. Furthermore, the large volume of data generated during HYCSOS operations, if handled and plotted manually, requires a considerable expenditure of time and effort. obviously, any solution to the problem of low measurement rate must also address the problem of large data volume. The addition of a Tektronix, Inc. model 4051 graphic computing system alleviated these problems and fulfilled a major portion of the design requirement for automatic system operation i.e., it can act as an "intelligent" 
system controller.

The Tektronix 4051 and its peripherals, a Tektronix 4662 interactive digital plotter, a Tektronix 4907 flexible disc mass storage device, a Tektronix 4923 digital cartridge tape drive, and a Tektronix 4641 matrix line printer, comprise the system data processing equipment. The 4051 is a small selfcontained computer system which utilizes an extended BASIC programming language, has extensive.graphics capability, and includes a full ASCII 128 character keyboard and direct view storage CRT as primary input/output devices. User workspace consists of $30 \mathrm{k}$ bytes of access memory (RAM). A built-in magnetic tape cartridge drive unit provides approximately $300 \mathrm{k}$ bytes/cartridge of data and program local storage. Communication between the 4051 and each device external to it is accomplished through one of two separate ports: an RS-232C (serial) data communications interface and an IEEE-488 (parallel) general purpose interface bus (GPIB). The 4662 digital plotter, a microprocessor controlled unit with a $25 \times 38 \mathrm{~cm}$ plotting surface, serves as the hardcopy output device for graphic data. Graphic data can consist of alphanumeric characters as well as vectors, and the characters can be scaled and rotated independently of plot size. A 1600 byte input buffer prevents the plotter from slowing system operation. The plotter can also be used as a digitizer to send coordinate information back to the computer from the plotter surface. Hardcopy output of program listings, 
test and numeric data is produced by the 4641 line printer. The 4907 "floppy disc" system is the primary data and control program storage device. The flexibility of its file and command structure, together with its large (1.8M byte) storage capacity and relatively. high speed (compared to mag tape) provide the necessary capability for fast data acquisition during both manual mode and eventual automatic mode HYCSOS operation. The 4907 system is microprocessor controlled and requires none of the 4051 RAM for its operation. Communication between the 4907 and $405 \perp$ is over the parallel (GPTB) bus.

The 4923 magnetic tape drive can be inserted into the serial (RS-232C) data link between the data logger and the computer such that its presence is transparent to either device. This permits system diagnostics involving communication between the data logger and the computer, as well as a back-up data logging capability.

\section{Operation}

The programmability of both the 4051 computer and the $2240 \mathrm{~B}$ data logger provides wide flexibility in the operation of the system. Depending on the requirements of the experiment, data can be logged on paper tape only, on paper tape and magnetic disc or tape simultaneously with the data processed and displayed or plotted later, or the data can be logged on a magnetic disc while selected channel data is processed and presented in realtime on the CRT and/or the plotter. Concurrently, data can be 
output to the line printer if required.

As no computer actually performs multiple tasks simultaneously, the throughput rate of channel data depends on the number and type of input/output operations per data scan as well as the operational speed of the computer. Because of this, tradeoffs must be made among scan rate, number of channels scanned, complexity of data processing steps involved, and type and quantity of output. Typical throughput rate with moderate processing requirement and outputting two or three channels to the CRT or plotter is about 8 measurement channels/sec.

In addition to real-time graphic presentation of process variables during HYCSOS operation, the data processing capability of the system permits rapid recall and plotting of previous data for comparisons, trend analysis, record keeping, visual presentation slides, etc.

\section{SYSTEM OPERATION}

The Argonne HYCSOS system was designed and constructed as a facility to evaluate materials and components as candidates for use in the hydride chemical heat pump concept. Since most hydride materials are relatively expensive, economic considerations require rapid cycling to obtain maximum thermal benefits. Measurement of rapid thermal and pressure transients are thus important for the evaluation of materials and components. The HYCSOS instrumentation and data handling. system is designed to measure system transients and output data for further evaluation. 
In multichannel logging, HYCSOS data can be collected at rates up to eight channels per second. Successive readings of a single channel can be recorded up to four per second.

A. System Transient Measurements

The performance of old hydride beds cycled at least 70 times was compared with that of new beds which had been hydrided and dehydrided about 10 times including the initial activation of three cycles. With an initial composition near the center of the plateau in both old and new alloy beds, approximately 5 moles of hydrogen were transferred from LaNi 5 to CaNi 5 (Run 89) and then back (Run 90). The old and new heat exchangers were in parallel for the appropriate heat transfer fluid (HTF) loops. The data channels, temperature, hydrogen pressure, fluid flow and hydrogen mass transfer, were read at 12 second intervals. Figures 14 and 15 compare the performance of the old hydride beds, HHE-2 and HHE-3; and the new beds, HHE-1 and HHE-4. The hydrogen pressure behavior of the old beds (channels 45 and 46) and the new beds (channels 44 and 47) are similar and show no deterioration of the old beds. Although the $18 \mathrm{kw}$ heaters were able to keep constant the inlet temperatures (channels 13 and 15, Figure 15a) during desorption from CaNi $_{5}$, the water chiller (2200 btu/hr heat removal) was not able to maintain the inlet temperature during absorption on $\mathrm{LaNi}_{5}$ (channels 17 and 19, Figure 15b). Note also the increase in low temperature flow rate (channels 50 and 51, Figure 15b) with increase in temperature 
due to decrease in viscosity of the ethylene glycol-water heat transfer fluid.

Figure 16 compares hydrogen desorption at $39^{\circ} \mathrm{C}$ (Run 89) and at $59^{\circ} \mathrm{C}$ (Run 9l) from $\mathrm{LaNi}_{5}$. In half the transfer time at $59^{\circ} \mathrm{C}, 12$ seconds, more hydrogen was transferred than in 24 seconds at the lower temperature. In both cases absorption was on $\mathrm{CaNi}_{5}$ at $14^{\circ} \mathrm{C}$.

A comparison of hydrogen transfer as a function of heat transfer fluid flow rate is shown in Figure 17. Approximately 5 moles of hydrogen were transferred from $\mathrm{CaNi}_{5}$ at $106^{\circ} \mathrm{C}$ to $\mathrm{LaNi}_{5}$ at $8^{\circ}$ at fluid flow rates between $3-121 / \mathrm{m}$ for the desorbing units and $2.7-7.31 / \mathrm{m}$ for the absorbing alloy beds. At the lowest flow rates in both cases the hydrogen behavior, as monitored by hydrogen pressure, is slower. Heat removal at flow rates below $3 \mathrm{l} / \mathrm{m}$ has apparently become slow enough to affect the heat, transfer from the hydride bed. Since film coefficients are large, the insensitivity of hydrogen behavior to heat transfer fluid flow rate at the high flow rates would indicate these reactions to be heat transfer limited with the slow step being the transfer of heat from the reaction site in the bed to the first wall of the heat transfer fluid tube. The more rapid temperature recovery at the fast flow, Figure 17a, is because of a shorter hydrogen transfer time and so an earlier recovery start: The longer cycle temperature filuctuations of the low flow rate follow the cycling of the heater input. 
The heat transfer characteristics of the hydride heat exchangers can also be evaluated by comparing the temperature of the hydride bed with the temperature of the heat transfer fluid leaving the heat exchanger. The bed temperature, calculated from the measured hydrogen pressure using the appropriate hydride vapor pressure equation and assuming rapid gas sorption kinetics, is a measure of the lowest bed temperature. Figure 18 compares the bed temperature, normalized to the fluid temperature at 15 minutes, with the heat transfer fluid temperature for both absorption and desorption of approximately 6 moles of hydrogen. The large lag of the bed temperature shows the relatively slow heat transfer between the bed and the fluid.

A quantitative measure of the heat transfer in the beds can be obtained from the time for half recovery of the temperature after cessation of hydrogen transfer. Using the extrapolated peak and the bed temperature at 15 minutes for a peak base, the time for half peak-height recovery (Figure 18) as a function of fluid flow rate for hydriding processes is listed in Table 4. For flow rates above $31 / \mathrm{m}$, the time to recover half the temperature is approximately 30 seconds. The sight bias in favor of the desorption process for both alloys may indicate the slower, continued absorption of hydrogen and release of heat after hydrogen flow into the chamber has ended. The slower recovery, 44 seconds, at lower flow rates 
is consistent with the previous (Figure 17) observation that fluid heat removal becomes limiting at flows below. $31 \% \mathrm{~m}$.

Table 4. Time for Half Temperature Recovery

\begin{tabular}{|c|c|c|c|c|}
\hline Process & HTF & $\begin{array}{l}\text { flow rate } \\
(1 / \mathrm{m})\end{array}$ & : Time: & $\begin{array}{l}1 / 2 \text { recovery } \\
(\mathrm{sec})\end{array}$ \\
\hline Desorb. $\mathrm{CaNi}_{5}$ & . & 12.1 & & 28 \\
\hline Desorb. $\mathrm{CaNi}_{5}$ & & 3.0 & & 44 \\
\hline Desorb. $\operatorname{LaNi}_{5}$ & & 7.2 & & 28 \\
\hline Absorp. CaNi ${ }_{5}$ & & 5.2 & & 35 \\
\hline Absorp. LaNi $_{5}$ & & 7.3 & & 33 \\
\hline Absorp. $\mathrm{LaNi}_{5}$ & & 2.7 & & 44 \\
\hline Absorp. LaNi $_{5}$ & Al & Foam HHE & & 4.5 \\
\hline
\end{tabular}

The limiting effect of fluid heat removal could cause the time for absorption and desorption to be the same if the rate of heat removal was slow compared to the heat addition after hydrogen transfer has ended. The time for half recovery for the LaNi 5 loaded a Luminum foam test module heat exchanger, Figures 7 and 8 , for a similar, but not the same, experiment, Figure 9, was about 4.5 seconds compared to 33 seconds for the coiled tube heat exchangers. The reduced hydride bed half thickness (see section IV B3) is responsible for the improved heat transfer. 


\section{B. Simulated Cooling Cycle}

An effort was made to simulate a complete cooling cycle. Hydrogen was transferred from $\mathrm{CaNi}_{5}$ hydride (HHE-1) at $110^{\circ} \mathrm{C}$ to $\mathrm{LaNi}_{5}(\mathrm{HHE}-4)$ at $33^{\circ} \mathrm{C}$ while at the same time hydrogen was desorbed from LaNi 5 hydride (HHE-3) in the cooling loop at $9^{\circ} \mathrm{C}$ and absorbed on $\mathrm{CaNi}_{5}(\mathrm{HHE}-2)$ at $33^{\circ} \mathrm{C}$ for cooling cycle I. The hydrogen and heat transfer fluid flows were then reversed so hydrogen was tranofcrred from $\mathrm{CaNi}_{5}$ hydrido (HHE-2) at $110^{\circ}$ to $\mathrm{LaNi}_{5}(\mathrm{HHE}-3)$ at $33^{\circ}$ and from $\mathrm{LaNi}_{5}(\mathrm{HHE}-4)$ at $9^{\circ}$ to $\mathrm{CaNi}_{5}$ (HHE-1) at $33^{\circ}$ for cooling Cycle II. Base line integrated power, that required to maintain the fluid loop and hydride heat exchanger at constant temperature without reaction, was measured for loop $\mathrm{A}$, the high temperature $100 \mathrm{p}$, to be $15.70 \mathrm{kcal} / \mathrm{min}$, and for loop $\mathrm{C}$, the cooling loop, to be $2.31 \mathrm{kcal} / \mathrm{min}$. The net increase in loop A integrated power (I.P.A.) is the high lemperature heat input required to dissociate the $\operatorname{CaN1}_{5}$ hydride. The net increase in loop $C$ integrated power (I.P.C.) is heat required to balance the cooling effect of hydrogen desorption in the cooling loop and maintain a constant temperature. The measured coefficient of performance for cooling is

$$
\mathrm{COP}_{\mathrm{C}}=\frac{\text { I.P.C. }}{\text { I.P.A. }}
$$

For this simulatịon, hydrogen valves were left open and heat transfer fluid loops were manually switched at cycle times of about 7-10 minutes with data taken at 1 minute intervals. Five complete cycles were run starting with a thermally 
equilibrated system. Data for the first Cooling Cycle I, is given in Figure 19. Corrected for the lower hydrogen transfer in the cooling loop of the cycle, the coefficient of performance is measured to be

$$
\begin{aligned}
\operatorname{COP}_{\mathrm{C}} & =\frac{\text { I.P.C. }}{\text { I.P.A. }} \times \frac{\mathrm{H}_{2}(\mathrm{HHE}-1+\mathrm{HHE}-4)}{\mathrm{H}_{2}(\mathrm{HHE}-3 \rightarrow \mathrm{HHE}-2)} \\
& =\frac{44.37 \mathrm{kcal}}{123.27 \mathrm{kcal}} \times \frac{17.30 \mathrm{MOle}}{5.77 \mathrm{MOle}}=1.1 .
\end{aligned}
$$

Using the general heat pump equation for cooling cycles (Section II) and the experimental temperatures, $\mathrm{T}_{\mathrm{h}}=383^{\circ} \mathrm{K}, \mathrm{T}_{\mathrm{m}}=308^{\circ} \mathrm{K}$ and $\mathrm{T}_{\ell}=283^{\circ} \mathrm{K}$, a theoretical coefficient of performance of 2.1 is calculated. A similar measurement for other cycles would be less meaningful because lack of regenerative heat exchange coupled with the large heat capacity of the loop external to the heat exchanger would require substantial amount of heat to arrive at the starting temperatures. The temperatures used were not optimum and should be selected to prevent hydrogen buildup in one heat exchanger.

\section{Thermal Conductivity}

Thermal conductivity is an important characteristic determining heat transfer of powder beds. Lehrfeld and Boser (36) have: measured an effective thermal conductivity of activated LaNi ${ }_{5}$, Figure 20, and found that filling factor, the ratio of powder packing density to the bulk material density, affects thermal conductivity more strongly than either temperature or hydrogen pressure. This finding is consistent with the generally 
accepted model that conduction in a powder bed is limited by the point contact between adjacent particles and the greater the compression the higher is the thermal conduction. To be better able to evaluate and compare heat exchangers (see Section IV B3), the conductivity of the alloy beds in the current coiled tube hydride heat exchangers was calculated. Because the heat flow is through the cylindrical wall of the fluid tubes, the model selected is a conduction cross section path proportional to the radius. $(40)$ since the effective bed diameter is not large compared to the fluid tube diameter, the thermal conductivity of the hydride bed, $k$, can be approximated by

$$
\begin{aligned}
\mathrm{k} & =\mathrm{Qd} /(\Delta \mathrm{t} \cdot \mathrm{a} \cdot \mathrm{T}) \text { where } \\
\mathrm{Q} & =\text { quantity of heat transferred } \\
\mathrm{d} & =\text { length of conduction path } \\
\Delta \mathrm{t} & =\text { temperature difference across the bed } \\
\mathrm{d} & =\text { fluid heat transfer surface area } \\
\mathrm{T} & =\text { time of heat flow }
\end{aligned}
$$

The 5.74 mole transfer of hydrogen from $\mathrm{CaNi}_{5}$ to $\mathrm{LaNi}_{5}{ }^{\prime}$ Figures $18 \mathrm{c}$ and $18 \mathrm{~d}$, was used to provide the temperature difference between the bed and the heat transfer fluid. The bed temperature was determined from the hydrogen pressure and the approprlate van't Hoft equation, while for the heat transfer fluid in the coiled tubes, the average of the inlet and outlet temperature was used. Temperature and pressure readings 
were taken at 20 second intervals for the first two minutes of hydrogen desorption from $\mathrm{CaNi}_{5}$ and absorption on $\mathrm{LaNi}_{5}$ at which time the inlet water temperature to the $\mathrm{CaNi}_{5}$ heat exchanger re-established its original value. From the design specifications of the heat exchangers, the change in free gas volume after addition of the alloy and the weight of alloy added, the surface area of the heat transfer fluid and the bulk density of the alloy were calculated. The bed thickness, $0.32 \mathrm{~cm}$, was taken as half the distance between adjacient fluid coils in the bed. A powder density of $4 \mathrm{~g} / \mathrm{ml}$, determined for lightly poured $\operatorname{LaNi}_{5}$, was used to obtain the filling factor. The accepted heat of reaction, $7.5 \mathrm{kcal} / \mathrm{mole}$ for $\mathrm{CaNi}_{5}$ and $7.2 \mathrm{kcal} / \mathrm{mole}$ for $\mathrm{LaNi}_{5}$, was used to calculate the quantity of heat transferred. The results of the conductivity determination are shown in Table 5.

Table 5. Thermal Conductivity of $\mathrm{CaNi}_{5} \mathrm{Hydride}$ and $\mathrm{LaNi}_{5} \mathrm{Hydride}$

\begin{tabular}{|c|c|c|c|c|c|}
\hline Comp. Range & $\begin{array}{c}\text { Heat } \\
(\text { kcal })\end{array}$ & $\begin{array}{c}\Delta t \\
\left({ }^{\circ} \mathrm{C}\right)\end{array}$ & $\begin{array}{c}\text { Surface } \\
\left(\mathrm{cm}^{2}\right)\end{array}$ & $\begin{array}{l}\text { Filling } \\
\text { Factor }\end{array}$ & $\begin{array}{l}\text { Conductivity } \\
\frac{\mathrm{Cal}}{{ }^{\circ} \mathrm{C} \cdot \mathrm{cm} \cdot \mathrm{sec}}\end{array}$ \\
\hline 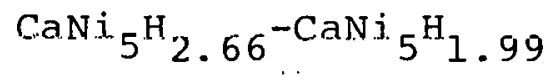 & 43.0 & 9.0 & 3125 & 0.6 & 0.0040 \\
\hline $\operatorname{LaNi}_{5} \mathrm{H}_{2} .26^{-\mathrm{LaNi}_{5} \mathrm{H}_{3} .30}$ & 41.3 & $9: 1$ & 2690 & 0.4 & 0.0045 \\
\hline $\mathrm{CaNi}_{5} \mathrm{H}_{2} .66^{-\mathrm{CaNi}_{5} \mathrm{H}_{1} .99}$ & 43.0 & 5.1 & 3125 & 0.6 & $0.0036 *$ \\
\hline
\end{tabular}


Although thermal conductivity measurements are, at best, approximate, the relative constancy of the determinations would indicate the importance of factors other than composition or filling factor, e.g., bed disruption during hydrogen mass transport, on the effective conductivity of powder beds in these heat exchangers.

\section{VI: CONCLUSIONS}

Under oontraot to the Argonne National Laboraloiy, TRW Energy Systems Division, McLeạ, Va. has independently evaluated the performance and cost effectiveness of the HYCSOS system. (41) The system design was optimized using an iterative computer program. To minimize regenerative heat losses, a freon heat transfer fluid is used and temperature changes of the hydride heat exchangers occur. when they contain gaseous freon. Due to the high cost of hydride materials, LaNi ${ }_{5}$ for the low temperature beds and either $\overline{C a N i}_{5}$ or aluminum substituted lanthanum nickel alloy for the high temperature bed, rapid cycling hydride beds was postulated with the hydride imbedded in open-pore aluminum foam with fins to augment thermal conductivity. To facilitate rapid cycling, the hydride beds were designed to maximize heat transfer while minimizing hydrogen pressure drop. Fiberglass paper filters are used to prevent migration of hydride powder. For the energy conversion cycle, an isothermal free-piston, double-acting expander is proposed. The piston would form an element of a reciprocating alternator. 
A computer program was developed to assist in the design process. The design heat transfer rate, the aluminum foam and fin thermal conductivity augmentation of the hydride, the outside air temperature drop, and the aluminum doping of the hydride material were all varied to optimize the cost and performance (COP) of the HYCSOS system. The system was optimized for six design temperatures (temperatures for rated winter heat pump operation). Tables 6 and 7 show the result of the design program process for three sizes of HYCSOS with electrical power generation and for the range of design temperatures.

The system price was estimated by including, the cost of all components, an assembly charge and a generic markup of $2.4 \mathrm{x}$ (for distribution, profit, and selling costs). The computer program was used to optimize cost and performance assuming an increase in. COP of 0.1 for the 22,000 BtuH size was worth $\$ 600$. (by reducing collector size). Table 8 shows the proportion of the system price and the amount attributable to the major components.

The system performance is dascribed by the coefficient of performance (COP), and the system output of heat and of cooling. The coefficient of performance of the overall system is determined from the thermal losses due to cycling the hydride beds and due to the auxiliary power consumed by freon pumps and air-moving fans. The systems are designed to a "design point". 
TABLE 6. HYCSOS CONPONENT SIZING AND POWER CONSUMPTION

\begin{tabular}{|c|c|c|c|c|c|c|c|c|c|}
\hline \multirow{2}{*}{$\begin{array}{c}\text { WINTER } \\
\text { DESIGN } \\
\text { TEMP } \\
\left({ }^{\circ}\right)\end{array}$} & \multirow{2}{*}{$\begin{array}{l}\text { DESIGN } \\
\text { HEAT } \\
\text { OUTPUT } \\
\text { (TONS) }\end{array}$} & \multirow{2}{*}{$\begin{array}{l}\text { BED } \\
\text { AREA } \\
\left(F T^{2}\right)\end{array}$} & \multicolumn{2}{|c|}{ HYDRIDE MASS } & \multicolumn{2}{|c|}{ HX FACE AREA } & \multicolumn{2}{|c|}{ FAN POWER } & \multirow{2}{*}{$\begin{array}{c}\text { PUMP } \\
\text { POWER } \\
\text { (WATTS) }\end{array}$} \\
\hline & & & $\begin{array}{l}\text { LT3*. } \\
\text { (1LBS) }\end{array}$ & $\begin{array}{l}\text { HTB* } \\
\text { (1 LBS) }\end{array}$ & $\begin{array}{c}\text { INDOOR } \\
\left(\mathrm{FT}^{2}\right)\end{array}$ & $\begin{array}{c}\text { OUTDOOR } \\
\text { (FT }^{2} ;\end{array}$ & $\begin{array}{l}\text { INDOOR } \\
\text { (WATTS) }\end{array}$ & $\begin{array}{l}\text { OUTDOOR } \\
\text { (WATTS) }\end{array}$ & \\
\hline 25 & $\begin{array}{l}1.84 \\
4.57 \\
2.99^{* *}\end{array}$ & $\begin{array}{l}1.58 \\
3.90 \\
7.81\end{array}$ & $\begin{array}{r}2.59 \\
6.41 \\
12.83\end{array}$ & $\begin{array}{r}3.41 \\
8.45 \\
16.91\end{array}$ & $\begin{array}{r}2.5 \\
6.3 \\
12.5\end{array}$ & $\begin{array}{r}4.4 \\
10.9 \\
21.8\end{array}$ & $\begin{array}{r}333 \\
824 \\
1649\end{array}$ & $\begin{array}{l}132 \\
328 \\
656\end{array}$ & $\begin{array}{r}77 \\
155 \\
382\end{array}$ \\
\hline 30 & $\begin{array}{l}1.84 \\
4.57 \\
3.01\end{array}$ & $\begin{array}{l}1.39 \\
3.44 \\
6.83\end{array}$ & $\begin{array}{r}2.61 \\
6.46 \\
12.84\end{array}$ & $\begin{array}{r}3.40 \\
8.42 \\
16.74\end{array}$ & $\begin{array}{r}2.5 \\
6.3 \\
12.4\end{array}$ & $\begin{array}{r}4.5 \\
11.2 \\
22.1\end{array}$ & $\begin{array}{r}333 \\
824 \\
1638\end{array}$ & $\begin{array}{l}135 \\
335 \\
666\end{array}$ & $\begin{array}{r}76 \\
188 \\
373\end{array}$ \\
\hline 35 & $\begin{array}{l}1.84 \\
4.57 \\
3.01\end{array}$ & $\begin{array}{l}1.13 \\
2.79 \\
5.43\end{array}$ & $\begin{array}{r}2.63 \\
6.52 \\
12.70\end{array}$ & $\begin{array}{r}3.42 \\
8.47 \\
16.50\end{array}$ & $\begin{array}{r}2.5 \\
6.3 \\
12.2\end{array}$ & $\begin{array}{r}4.6 \\
11.5 \\
22.4\end{array}$ & $\begin{array}{r}333 \\
824 \\
1606\end{array}$ & $\begin{array}{l}140 \\
346 \\
673\end{array}$ & $\begin{array}{r}79 \\
195 \\
308\end{array}$ \\
\hline 40 & $\begin{array}{l}1.84 \\
4.57 \\
3.00\end{array}$ & $\begin{array}{l}1.01 \\
2.49 \\
4.82\end{array}$ & $\begin{array}{r}2.64 \\
6.54 \\
1266\end{array}$ & $\begin{array}{r}3.41 \\
8.44 \\
16.34\end{array}$ & $\begin{array}{r}2.5 \\
6.3 \\
12.1\end{array}$ & $\begin{array}{r}4.7 \\
11.6 \\
22.5\end{array}$ & $\begin{array}{r}333 \\
824 \\
1595\end{array}$ & $\begin{array}{l}142 \\
350 \\
678\end{array}$ & $\begin{array}{r}79 \\
196 \\
379\end{array}$ \\
\hline 45 & $\begin{array}{l}1.84 \\
4.57 \\
3.00\end{array}$ & $\begin{array}{l}1.91 \\
4.73 \\
8.54\end{array}$ & $\begin{array}{r}284 \\
7.02 \\
12.70\end{array}$ & $\begin{array}{r}4.21 \\
10.43 \\
18.85\end{array}$ & $\begin{array}{r}2.5 \\
6.3 \\
11.3\end{array}$ & $\begin{array}{r}8.4 \\
20.8 \\
37.5\end{array}$ & $\begin{array}{r}333 \\
824 \\
1490\end{array}$ & $\begin{array}{r}252 \\
625 \\
1130\end{array}$ & $\begin{array}{r}55 \\
137 \\
247\end{array}$ \\
\hline 47 & $\begin{array}{l}1.84 \\
4.56 \\
2.99\end{array}$ & $\begin{array}{l}2.01 \\
4.97 \\
8.97\end{array}$ & $\begin{array}{r}4.21 \\
10.41 \\
18.38\end{array}$ & $\begin{array}{r}6.24 \\
15.46 \\
27.28\end{array}$ & $\begin{array}{r}2.5 \\
6.1 \\
10.8\end{array}$ & $\begin{array}{r}6.3 \\
15.7 \\
27.6\end{array}$ & $\begin{array}{r}325 \\
805 \\
1421\end{array}$ & $\begin{array}{l}190 \\
471 \\
832\end{array}$ & $\begin{array}{r}55 \\
137 \\
242\end{array}$ \\
\hline
\end{tabular}

$\angle T B=$ LOW TEMPERATURE BED

HTB = HIGH TEMPERATURE BED

"*COLING OUTPUT 
TABLE 7 . RESULTS OF DESIGN OPTIMIZATION

\begin{tabular}{|c|c|c|c|c|c|c|c|c|c|c|c|c|}
\hline \multirow{2}{*}{$\begin{array}{l}\text { WIMTER DESIGN } \\
\text { TEMPEFATURE } \\
\text { (OF) }\end{array}$} & \multirow{2}{*}{$\begin{array}{l}\text { HIGH TEMPERATURE } \\
\text { BED COMPOSITION }\end{array}$} & \multirow{2}{*}{$\begin{array}{c}\text { EQUIVALENT } \\
\text { FOAM DENSITY } \\
(\%)\end{array}$} & \multirow{2}{*}{$\begin{array}{c}\text { FIN } \\
\text { THICKNESS } \\
\text { (IUCHES) }\end{array}$} & \multirow{2}{*}{$\begin{array}{c}\text { FOAM } \\
\text { DENSITY } \\
(\%)\end{array}$} & \multicolumn{2}{|c|}{$\begin{array}{l}\text { BED DEPTH } \\
\text { (INCHES) }\end{array}$} & \multirow{2}{*}{$\begin{array}{l}\text { ABSORPTION- } \\
\text { DESORPTION } \\
\text { TIME (MINUTES) }\end{array}$} & \multirow{2}{*}{$\begin{array}{c}\text { REGENERATION } \\
\text { TIME } \\
\text { (MINUTES) }\end{array}$} & \multicolumn{2}{|c|}{$\begin{array}{c}\text { SDLAR INPUT } \\
\text { TEMPERATURE ( }{ }^{\circ} \text { F) }\end{array}$} & \multirow{2}{*}{$\begin{array}{c}\text { OUTDOOR AIR } \\
\text { TEMPERATURE } \\
\text { CHANGE } \\
\left({ }^{\circ} \mathrm{F}\right)\end{array}$} & \multirow{2}{*}{$\begin{array}{l}\text { HYDRIOE BED OESIGM } \\
\text { HEAT IRANSFER RATE } \\
\text { (ETUH /FT') }\end{array}$} \\
\hline & & & & & MTB & LTB & & & WINTER & SUMMER & & \\
\hline 30 & LaNi $_{4.59 \mathrm{Al}_{.41}}$ & 35 & .020 & 6.7 & .262 & .201 & 1 & .16 & 254 & 277 & 5 & 7200 \\
\hline 35 & LaNi 4595 Al $_{.405}$ & 35 & .021 & 4.9 & .325 & .250 & 1 & .16 & 257 & 280 & 5 & 8950 \\
\hline 45 & $\mathrm{Ca} \mathrm{Ni} 5$ & 35 & .020 & 6.7 & .236 & .159 & 1 & .16 & 211 & 224 & 3 & 5700 \\
\hline 47 & $\mathrm{CaNi}_{5}$ & 35 & .021 & 4.9 & .333 & .224 & 1.5 & .20 & 212 & 229 & 4 & 5350 \\
\hline
\end{tabular}


TABLE 8. HYCSOS COMPONENT PRICE BREAKDOWN AND TOT.ニL PRICE

\begin{tabular}{|c|c|c|c|c|c|c|c|}
\hline $\begin{array}{c}\text { WINTER } \\
\text { DESIGN } \\
\text { TEMPERATURE }\end{array}$ & $\begin{array}{c}\text { HEAT } \\
\text { OUT } \\
\text { (TONS) }\end{array}$ & $\begin{array}{c}\text { HYDRIDE } \\
\text { BEDS } \\
\$\end{array}$ & $\begin{array}{c}\text { FREON \& } \\
\text { PLUMBING } \\
\$\end{array}$ & $\begin{array}{c}\text { INDOOR } \\
\text { HX \& FAV } \\
\$\end{array}$ & $\begin{array}{l}\text { QUTDOOR } \\
\text { HX \& FAN } \\
\$\end{array}$ & $\begin{array}{c}\text { EXPANDER- } \\
\text { ALTERNATOR } \\
\$\end{array}$ & $\begin{array}{l}\text { UNINSTALLED } \\
\text { SYSTEM TOTAL } \\
\text { PRICE } \\
\$\end{array}$ \\
\hline 25 & $\begin{array}{l}1.84 \\
4.57 \\
9.14\end{array}$ & $\begin{array}{r}247.14 \\
611.96 \\
1223.91\end{array}$ & $\begin{array}{l}116.82 \\
213.58 \\
348.31\end{array}$ & $\begin{array}{r}70.26 \\
159.21 \\
308.41\end{array}$ & $\begin{array}{r}71.86 \\
177.93 \\
355.87\end{array}$ & $\begin{array}{l}253 \\
270 \\
376\end{array}$ & $\begin{array}{l}1295 \\
2245 \\
3806\end{array}$ \\
\hline 30 & $\begin{array}{l}1.84 \\
4.57 \\
9.08\end{array}$ & $\begin{array}{r}241.99 \\
599.20 \\
1190.46\end{array}$ & $\begin{array}{l}117.00 \\
214.01 \\
347.49\end{array}$ & $\begin{array}{r}70.26 \\
159.21 \\
306.44\end{array}$ & $\begin{array}{r}73.55 \\
182.12 \\
361.82\end{array}$ & $\begin{array}{l}253 \\
270 \\
376\end{array}$ & $\begin{array}{l}1291 \\
2236 \\
3768\end{array}$ \\
\hline 35 & $\begin{array}{l}1.84 \\
4.57 \\
8.90\end{array}$ & $\begin{array}{r}235.83 \\
583.96 \\
1137.58\end{array}$ & $\begin{array}{l}117.21 \\
214.54 \\
343.61\end{array}$ & $\begin{array}{r}70.26 \\
159.21 \\
300.66\end{array}$ & $\begin{array}{r}75.78 \\
187.63 \\
365.52\end{array}$ & $\begin{array}{l}253 \\
271 \\
374\end{array}$ & $\begin{array}{l}1287 \\
2226 \\
3689\end{array}$ \\
\hline 40 & $\begin{array}{l}1.84 \\
4.57 \\
8.84\end{array}$ & $\begin{array}{r}232.29 \\
575.19 \\
1113.27\end{array}$ & $\begin{array}{l}117.31 \\
214.80 \\
342.52\end{array}$ & $\begin{array}{r}70.26 \\
159.21 \\
298.79\end{array}$ & $\begin{array}{r}76.84 \\
190.27 \\
368.26\end{array}$ & $\begin{array}{l}253 \\
268 \\
373\end{array}$ & $\begin{array}{l}1284 \\
2215 \\
3657\end{array}$ \\
\hline 45 & $\begin{array}{l}1.84 \\
4.57 \\
8.26\end{array}$ & $\begin{array}{l}200.84 \\
497.31 \\
898.75\end{array}$ & $\begin{array}{l}130.52 \\
247.50 \\
385.09\end{array}$ & $\begin{array}{r}70.26 \\
159.21 \\
279.65\end{array}$ & $\begin{array}{l}137.05 \\
339.36 \\
613.30\end{array}$ & $\begin{array}{l}253 \\
269 \\
356\end{array}$ & $\begin{array}{l}1334 \\
2341 \\
3687\end{array}$ \\
\hline 47 & $\begin{array}{l}1.84 \\
4.56 \\
8.05\end{array}$ & $\begin{array}{r}274.00 \\
678.47 \\
1197.30\end{array}$ & $\begin{array}{l}123.52 \\
230.18 \\
347.61\end{array}$ & $\begin{array}{r}68.87 \\
155.78 \\
267.25\end{array}$ & $\begin{array}{l}103.34 \\
255.89 \\
451.58\end{array}$ & $\begin{array}{l}253 \\
263 \\
343\end{array}$ & $\begin{array}{l}1371 \\
2428 \\
3772\end{array}$ \\
\hline
\end{tabular}


The heating design point and cooling design point use the ARI standards for indoor conditions $168^{\circ} \mathrm{F}$ indoors in winter and $78^{\circ} \mathrm{F}$ induors in summer). In addition, the ARI summer outdoor design temperature is $90^{\circ} \mathrm{F}$ and the winter outdoor design point is $47^{\circ} \mathrm{F}$. The output at $17^{\circ} \mathrm{F}$ is also used by the ARI. The HYCSOS was designed to a varying set of outdoor winter design temperatures.

Table 9 gives the system performance at the heating and cooling design temperatures. The COP including the electrical draw and excluding it are given.

The electrical output while heating is less than the electrical output while rejecting the heat outdoors because the power requirement for the indoor fan is higher than the outdoor fan. The use of a lower indoor fan speed would result in a somewhat higher net average power during power generation with indoor heating.

A solar absorption cooling system to provide 3 tons of cooling currently retails for $\$ 3000$ excluding à cooling tower, which is expensive, and an indoor heat exchanger. The HYcsos system to provide 3 tons of cooling would cost $\$ 3700$ to $\$ 3800$, including all heat exchangers. HYCSOS also provides heating with a COP greater than one and electrical power, although it requires a higher solar input than the absorption unit $\left(250^{\circ}\right.$ to $280^{\circ} \mathrm{F}$ as compared with $\left.180^{\circ} \mathrm{F}\right)$, and has slightly lower cooling 
TABLE 9. HYCSOS DESIGN POINT PERFORMANCE

\begin{tabular}{|c|c|c|c|c|c|c|c|c|c|c|}
\hline \multirow{3}{*}{$\begin{array}{c}\text { WINTER } \\
\text { DESIGN TEMPERATURE } \\
\text { OF }\end{array}$} & \multirow{2}{*}{\multicolumn{2}{|c|}{ SIZE }} & \multirow{3}{*}{$\begin{array}{l}\text { SOLAR } \\
\text { NPUT } \\
\text { HEAT } \\
\text { (TONS: }\end{array}$} & \multicolumn{4}{|c|}{ COEFFICIENT OF PERFORMANCE } & \multirow{2}{*}{\multicolumn{2}{|c|}{$\begin{array}{l}\text { ELECTRICAL } \\
\text { OUTPUT (KW) }\end{array}$}} & \multirow{3}{*}{$\begin{array}{l}\text { HEAT } \\
\text { OUTPUT } \\
\text { DURING } \\
\text { ELECTRICAL } \\
\text { GEMERATIOH } \\
\text { (TONS) }\end{array}$} \\
\hline & & & & \multicolumn{2}{|c|}{ HEATING } & \multicolumn{2}{|c|}{ cooting } & & & \\
\hline & $\begin{array}{c}\text { TONS } \\
\text { HEATING }\end{array}$ & $\begin{array}{c}\text { TONS } \\
\text { COOLING }\end{array}$ & & $\begin{array}{l}\text { WITHOUT } \\
\text { ELECT }\end{array}$ & $\begin{array}{l}\text { WITH } \\
\text { ELECT }\end{array}$ & $\begin{array}{l}\text { WITHOUT } \\
\text { ELECT }\end{array}$ & $\begin{array}{l}\text { WITH } \\
\text { ELECT }\end{array}$ & PEAK & $\begin{array}{c}\text { MET } \\
\text { AVERAGE }\end{array}$ & \\
\hline 25 & $\begin{array}{l}1.84 \\
4.57 \\
9.14\end{array}$ & $\begin{array}{l}.6 \\
1.5 \\
2.99\end{array}$ & 1.132 & 1.635 & 1.443 & .536 & .5 & $\begin{array}{l}.93 \\
2.3 \\
4.47\end{array}$ & $\begin{array}{r}.42 \\
1.04 \\
2.08\end{array}$ & .96 \\
\hline 30 & $\begin{array}{l}1.84 \\
4.57 \\
8.90\end{array}$ & $\begin{array}{r}.61 \\
1.51 \\
3.01\end{array}$ & 1.114 & 1.653 & 1.456 & .548 & .511 & $\begin{array}{l}.93 \\
2.32 \\
4.6\end{array}$ & $\begin{array}{r}.44 \\
1.09 \\
2.16\end{array}$ & .94 \\
\hline 35 & $\begin{array}{l}1.84 \\
4.57 \\
8.90\end{array}$ & $\begin{array}{r}.62 \\
1.54 \\
3.01\end{array}$ & 1.106 & 1.677 & 1.473 & .566 & .526 & $\begin{array}{r}.94 \\
2.33 \\
4.55\end{array}$ & $\begin{array}{r}.46 \\
1.15 \\
2.23\end{array}$ & .92 \\
\hline 40 & $\begin{array}{l}1.84 \\
4.57 \\
8.84\end{array}$ & $\begin{array}{r}.63 \\
1.55 \\
3.00\end{array}$ & 1.099 & 1.689 & 1.481 & .573 & .532 & $\begin{array}{r}.95 \\
2.34 \\
4.53\end{array}$ & $\begin{array}{r}.47 \\
1.17 \\
2.26\end{array}$ & .91 \\
\hline 45 & $\begin{array}{l}1.84 \\
4.57 \\
8.26\end{array}$ & $\begin{array}{r}.67 \\
1.66 \\
3.00\end{array}$ & 1.044 & 1.768 & 1.506 & .642 & .58 & $\begin{array}{r}.90 \\
2.29 \\
4.14\end{array}$ & $\begin{array}{l}.39 \\
1.0 \\
1.8\end{array}$ & 1.10 \\
\hline 47 & $\begin{array}{l}1.84 \\
4.56 \\
8.05\end{array}$ & $\begin{array}{r}.68 \\
1.70 \\
2.99\end{array}$ & 1.027 & $1.793^{\circ}$ & 1.55 & .666 & .611 & $\begin{array}{r}.88 \\
2.18 \\
3.84\end{array}$ & $\begin{array}{r}.44 \\
1.09 \\
1.92\end{array}$ & 1.03 \\
\hline
\end{tabular}


COPs. Thus this HYCSOS systems, which can be packaged similar to a conventional heat pump, compares favorably with a solar absorption cooling/dircct solar healing unit. 
APPENDIX A

Data Logger Channel Function

CHANNEL

0 .

1 .

2 .

3.

4.

5.

6.

7.

8.

9.

10.

11.

12 .

13.

14

15

16.

17.

18.
CHANNEL FUNCTION

Loop A fluid temperature HA inlet. Loop A fluid temperature HA outlet. Loop B fluid temperature HXB inlet. Loop B fluid temperature HXB outlet. Loop C fluid temperature HC inlet. Loop C fluid temperature HC outlet. Loop $\mathrm{W}$ water supply temperature. Loop $\mathrm{W}$ water temperature $\mathrm{HXB}$ inlet. Loop $W$ water temperature HXB outlet. HHE-I $\mathrm{H}_{2}$ temperature. HHE-2 $\mathrm{H}_{2}$ temperature. HHE-3 $\mathrm{H}_{2}$ temperature. HHE-4 $\mathrm{H}_{2}$ temperature. $\mathrm{HHE}=1$ fluid temperature inlet. HHE-l fluid temperature outlet. HHE. 2 fluid tompcrature inlet. HHE-2 fluid temperature outlet. HHE-3 fluid temperature inlet. HHE-3 fluid temperature outlet. 
APPENDIX A (continued)

CHANNEL

19.

20.

21 .

22 .

23.

24 .

25 .

26.

27.

28.

29.

30.

31.

32.

33.

34 .

35.

36.

37 .

38.

39.

\section{CHANNEL FUNCTION}

HHE-4 fluid temperature inlet. HHE-4 fluid temperature outlet. Ambient air temperature.

HA surface temperature tube 1 .

HA surface temperature tube 2 .

HA surface temperature tube 3 .

Unused temperature channel.

Unused temperature channel.

Unused temperature channel.

Unused tempërature channel

Unused temperature channel.

Heater A Power Integrator.

Heater C Power Integrator.

Pump A Power Integrator.

Pump B Power Integrator.

Pump C Power Integrator.

Pump $\mathrm{W}$ Power Integrator.

$\mathrm{H}_{2}$ flow from HHE-1.

$\mathrm{H}_{2}$ integrated flow from $\mathrm{HHE}-1$.

$\mathrm{H}_{2}$ flow from $\mathrm{HHE}-2$.

$\mathrm{H}_{2}$ integrated flow from HHE-2. 
APPENDIX A (continued)

CHANNEL

40 .

41.

42 .

43.

44 .

45.

46.

47 .

48 .

49.

50 .

51.

52 .

53.

54.

55.

56.

$5 \overline{7}$.

58 .

59.

\section{CHANNEL FUNCTION}

$\mathrm{H}_{2}$ flow from $\mathrm{HHE}-3$.

$\mathrm{H}_{2}$ integrated. flow from $\mathrm{HHE}-3$.

$\mathrm{H}_{2}$ flow from $\mathrm{HHE}-4$.

$\mathrm{H}_{2}$ integrated flow from $\mathrm{HHE}-4$.

$\mathrm{H}_{2}$ pressure HHE-l.

$\mathrm{H}_{2}$ pressure $\mathrm{HHE}-2$.

$\mathrm{H}_{2}$ pressure HHE-3.

$\mathrm{H}_{2}$ pressure HHE-4.

Fluid flow rate through $\mathrm{HHE}-\mathrm{I}$.

Fluid flow rate through HHE-2.

Fluid flow rate through $\mathrm{HHE}-3$.

Fluid. flow rate through HHE-4.

Water flow through HXB.

Unused voltage channel.

Unused voltage channel.

Unused voltage channel.

Unused voltage channel.

Unused voltaqe channel.

Unused voltage channel.

Unused voltage channel. 
APPENDIX B

System Definitions and Abbreviations

1). F-lHTF $\cdot$ Heat transfer fluid flow rate through HHE-1.

2) :F-2HTF Heat transfer fluid flow rate through HHE-2.

3) F-3HTF Heat transfer fluid flow rate through HHE-3.

4) F-4HTF Heat transfer fluid flow rate through $\mathrm{HHE}-4$.

5). $\mathrm{HA} 18 \mathrm{kw}$ heater in loop $\mathrm{A}$.

6) $\mathrm{HC} \mathrm{kw}$ heater in loop $\mathrm{C}$.

7) HHE-1 Hydride heat exchanger containing 17.344 moles (5786 g) $\mathrm{CaNi}_{5}$

8) HHE-2 Hydride heat exchanger containing 17.344 moles $(5786 \mathrm{~g}) \cdot \mathrm{CaNi}_{5}$

9) HHE-3 Hydride heat exchanger containing 11.561 mole

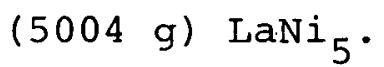

10): HHE-4 Hydride heat exchanger containing 11.561 mole (5004 g) $\operatorname{LaNi}_{5}$

11) HTF ' Heat transfer fluid.

12) $\therefore$ HXB $: 25 \mathrm{kw}$ heat exchanger in loop B.

13) IPA $\therefore$ Integrated heater power in loop A.

14) $\therefore$ IPC Integrated heater power in loop C.

15.) LOOP A Heat transfer fluid loop representing the solar or other thermal energy input. Contains $18 \mathrm{kw}$ electric heater. 
APPENDIX B (continued)

16) LOOP B Heat transfer fluid loop containing water cooled heat exchanger of $25 \mathrm{kw}$ heat transfer capacity. representing the space being heated in winter and serves for ambient heat rejection during cooling cycles.

17) LOOP C Heat transfer fluid lnnp with $6 \mathrm{kw}$ electric heater and $2200 \mathrm{BTU} / \mathrm{hr}$ heat removal capacity.

18) LOOP $\mathrm{W}$ vomestic water cooling for loop $B$.

19) $\mathrm{P}-\mathrm{IH}$ Hydrogen pressure in HHE-1.

20) $\mathrm{P}-2 \mathrm{H} \quad$ Hydrogen pressure in HHE-2.

21) $\mathrm{P}-3 \mathrm{H} \quad$ Hydrogen pressure in HHE-3.

22) $\mathrm{P}-4 \mathrm{H}$ Hydrogen pressure in $\mathrm{HHE}-4$.

23) T(bed) Temperature of hydride bed as calculated from appropriate vapor pressure equation.

24). T(outlet) Temperature of heat transfer fluid leaving HHE.

25) T-1HTF-I Temperature of heat transfer fluid entering HHE-1.

26) T-1HTF-O Temperature of heat transfer fluid leaving HHE-1.

27) T-2HTF-I Temperature of heat transfer fluid entering HHE-2.

28) T-2HTF-O Temperature of heat transfer fluid leaving HHE-2.

29) T-3HTF-I Temperature of heat transfer fluid entering HHE-3.

30) T-3HTF-O Temperature of heat transfer fluid leaving HHE-3.

31) T-4HTF-I Temperature of heat transfer fluid entering HHE-4.

32) T-4HTF-O Temperature of heat transfer fluid leaving HHE-4. 


\section{APPENDIX C}

\section{van't Hoff Vapor Pressure Equations}

$\mathrm{CaNi}_{5}$ Hydride

$$
\ln _{e} P(a t m)=-\frac{3778}{T}+11.97
$$

LaNi $_{5}$ Hyaride (desorption)

$$
\ln _{e} P(a t m)=-\frac{3632}{T}+13.14
$$

LaNi $_{5}$ Hydride (absorption)

$$
\ln _{\mathrm{e}} \mathrm{P}(\mathrm{atm})=-\frac{3013}{\mathrm{~T}}+11.39
$$




\section{REFERENCES}

1. P. Sporn, E. R. Ambrose and T. Baumeister, Heat Pumps, John Wiley and Sons, New York, 1947.

2. S. F. Gilman, Solar Energy Heat Pump Systems for Heating and Cooling of Buildings, Conference Proceedings available NTIS \#COO-2560-1; June, 1975.

3. S. C. Garg and A. W. Mcclaine, Metal Hydrides for Energy Storage Applications, Report'No. TNं-1393, available NTIS \#AD-AO141\%4, June, 1975.

4. Peter O'D. Offenhartz, Chemical Methods of Storing Thermal Energy, Proc. Joint Conference of the International Solar Energy Society and Solar Energy Society of Canada, Inc., Winnipeg, Canada, August, 1976.

5. D. M. Gruen and I. Sheft, Metal Hydride Systems for Solar Energy Conversion and Storage, Proc. NSF-ERDA Workshop on Solar Heating and cooling of Buildings, Charlottesville, Va., p. 96,1975

6. D. M. Gruen, et al., Proc. First World Hydrogen Energy Conference, Miami Beach, Fl., March, 1976.

7. D. M. Gruen, et al., Proc. 11th IECEC, State Line, Nev., p. 687, 1976.

8. I. Sheft, et al., HYCSOS: A System for Evaluation of Hydrides as Chemical Heat Pumps, Proc. International Symposium on Hydrides for Energy Storage, Geilo; Norway, Pergammon Press, New York, p. 551, 1977. 
9. D.. M: Gruen, et al., HYCSOS: A Chemical Heat Pump and Energy Conversion System Based on Metal Hydrides, Argonne National Laboratory Rcport ANL-77-39, 1977.

10. B. M. Gruen, M. H. Mendelsohn and I. Sheft, Metal Hydrides as Chemical Heat Pumps, Solar Energy, 21, 153, 1978.

11. R. L. Beck, Investigation of Hydriding Characteristics of Intermetallic Compounds, Denver Research Institute, University of Denver, USAEC Contract No. AT(33-3)3, Summary Report, DRI-2059, October, 1962.

12. K. H. J. Buschow and H. H. van Mal, J. Less-Common Metals, 29, 203, 1972 .

13. C. A. Bechman, A. Goady, T. Takeshita, W. E. Wallace and R. S. Craig, Inorg. Chem., 15, 2184, 1976.

14. C..E. Lundin, F. E. Lynch and C. B. Magee, Proc. 1.th IECEC, State Line, Nevada, p. 961, 1976.

15. D. M. Gruen, M. H. Mendelsohn and I. Sheft, Proc. Symp. Electrode Materials and Processes for Energy Conversion and Storage, $\underline{77-6}, 482,1977$.

16. M. H. Mendelsohn, D. M. Gruen and A. E. Dwight, Nature, $269,45, .1977$

17. F. A. Kuijpers, J. Less-Common Metals, 27, 27, 1971.

18: F. A. Kuijpers, Thesis, Technische Hochschule, Delft, 1973:

19. T. Takeshita, W. E. Wallace and R. S. Craig, Inorg. Chem., $\underline{13}, 2282,1974$ 
20. C. E. Lundin and F. E. Lynch, Denver Research Institute, First Annual Report, No. AFOSR, F44620-74-C0020, January, 1975 (DDC \#ADA006423).

21. J. L. Anderson, et. al., Los Alamos Report, LA-5320-MS, July, 1973 .

22. H. H. van Mal, K. H. J. Buschow and F. A. Kuijpers, J. Less-Common Metals, 32, 289, 1973.

23. H. H. van Mal, K. H. J. Buschow and A. R. Miedema, ibid, $35,65,1974$.

24. A. R. Miedema, ibld, 32, 117, 1973.

25. K. H. J. Buschow, H. H. van Mal and A. R. Miedema, ibid, $\underline{42}, 163,1975$.

26. A. R. Miedema, ibid, 46, 67, 1976.

27. K. H. J. Buschow and A. R. Miedema, Hydrogen Absorption into Rare Earth Intermetallic Compounds; Proc. International Symposium on Hydrides for Energy Storage, Geilo, Norwäy, Pergammon Press, Now York, p. 235, 1977.

28. A. R. Miedema, R. Boom and F. R. DeBoer, J. LessCommon Metals, 41, 283, 1975.

29. S. A. Steward, J. F. Lakner and F. Uribe, Lawrence Livermore Laboratory, UCRL-77455, 1976.

30. J. C. Achard, A. Percheron-Guegan, H, Diaz, F. Briancourt and F. Denany, 2nd Int'1. Cong. on Hydrogen in Metals, Paris, France, 1977.

31. T. Takeshita, S. K. Malik and W. E. Wallace, J. Solid State Chem., 271, 23, 1978. 
32. D. M. Gruen, M. Mendelsohn and A. Dwight, Advances in Chemistry Series, No. 173, American Chemical Society, Washington, D.C., 1978, p 279.

33. D. M. Gruen, M. Mendelsohn, I. Sheft and G. Lamich, Proc. .2nd world Hydrogen Energy Conf., Zurich, Switzerland, p. 1931, August, 1978.

34. G. D. Sandrock, ibid, p. 1625, August, 1978 .

35. N. Marzouk, R. S. Craig and W. E. Wallace, J. Phys. Chem. Solids, 34, 15, 1973.

36. D. Lehrfeld and O. Boser, Absorption-Desorption Compressor for Spaceborne/Airborne Cryogenic Refrigerators, Philips Laboratories Technical Report AFFDL-TR-74-21, p. 46, March, 1974 .

37. M. Ron, Proc. 11th IECEC, State Line, Nevada, p. 954, 1976. 38a. M. H. J. van Rijswick, Metal Hydrides for Electrochemical: Energy Storage, Proc. International Symposium for Energy Storage, Geilo, Norway, Pergammon Press, New York, p. 261, 1977.

38b. German Pátent \#2640345, 1977.

39. o. Bernauer, Workshop discussion, Hydride Storage Reservior Symposium, Brookhaven National Laboratory, Upton, New York, June 20-21, 1978.

40. W. H. Adams, Heat Transmission, McGraw-Hill, New York, p. 12, 1954.

41. R. Gorman and P. S. Moritz, Metal Hydride Solar Heat Pump and Power system (HYCSOS), PrOC. AIAA/ASERC Conference on Solar Energy: Technology Status, Phoenix, AZ, November, 1978. Paper No. 78-1762. 


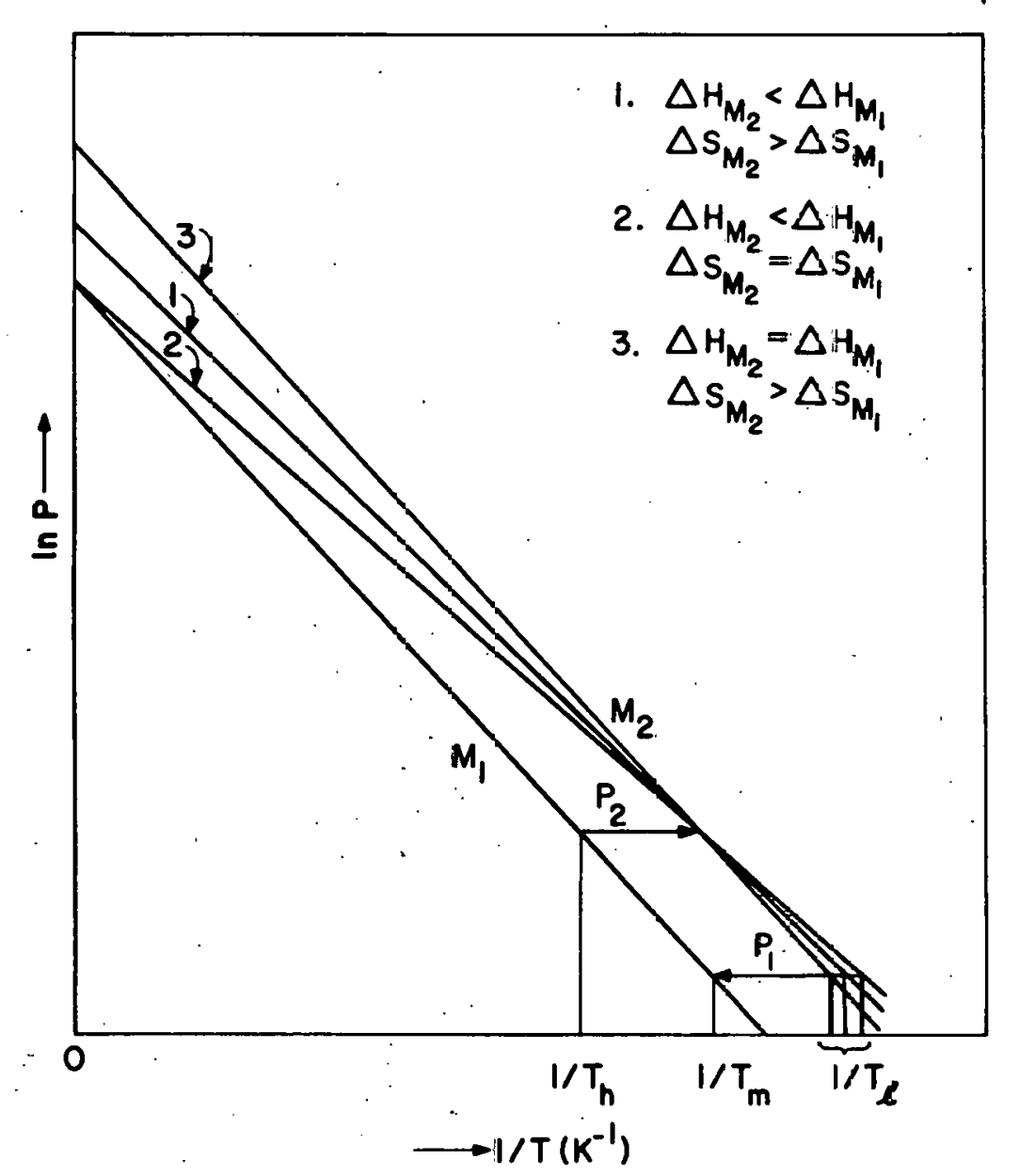

Fig. 1. Thermodynamics of Metal Hydride Chemical Heat Pumps

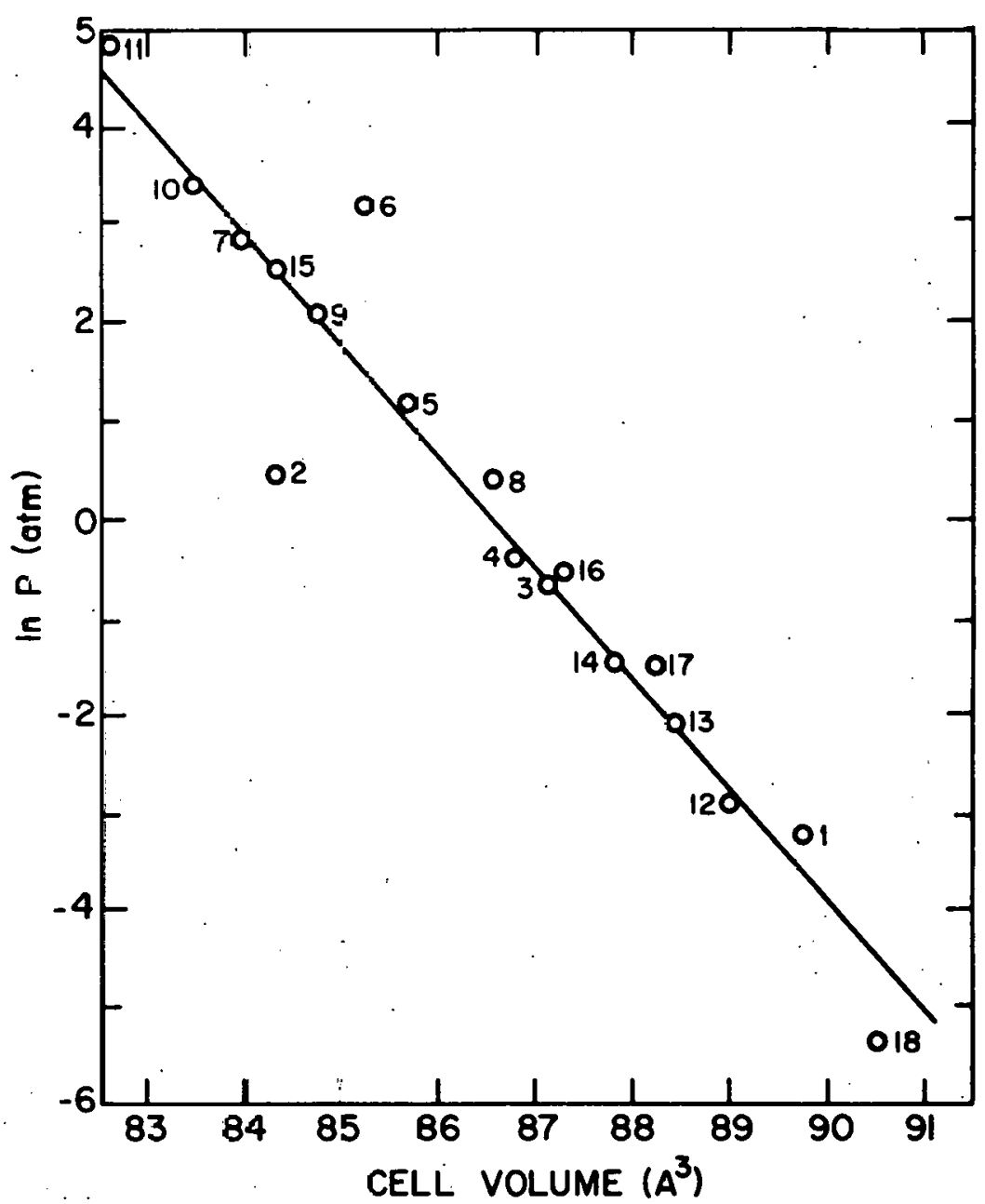

Fig. 2. Plateau Pressure vs Cell Volume for Some Alloy Hydrides 


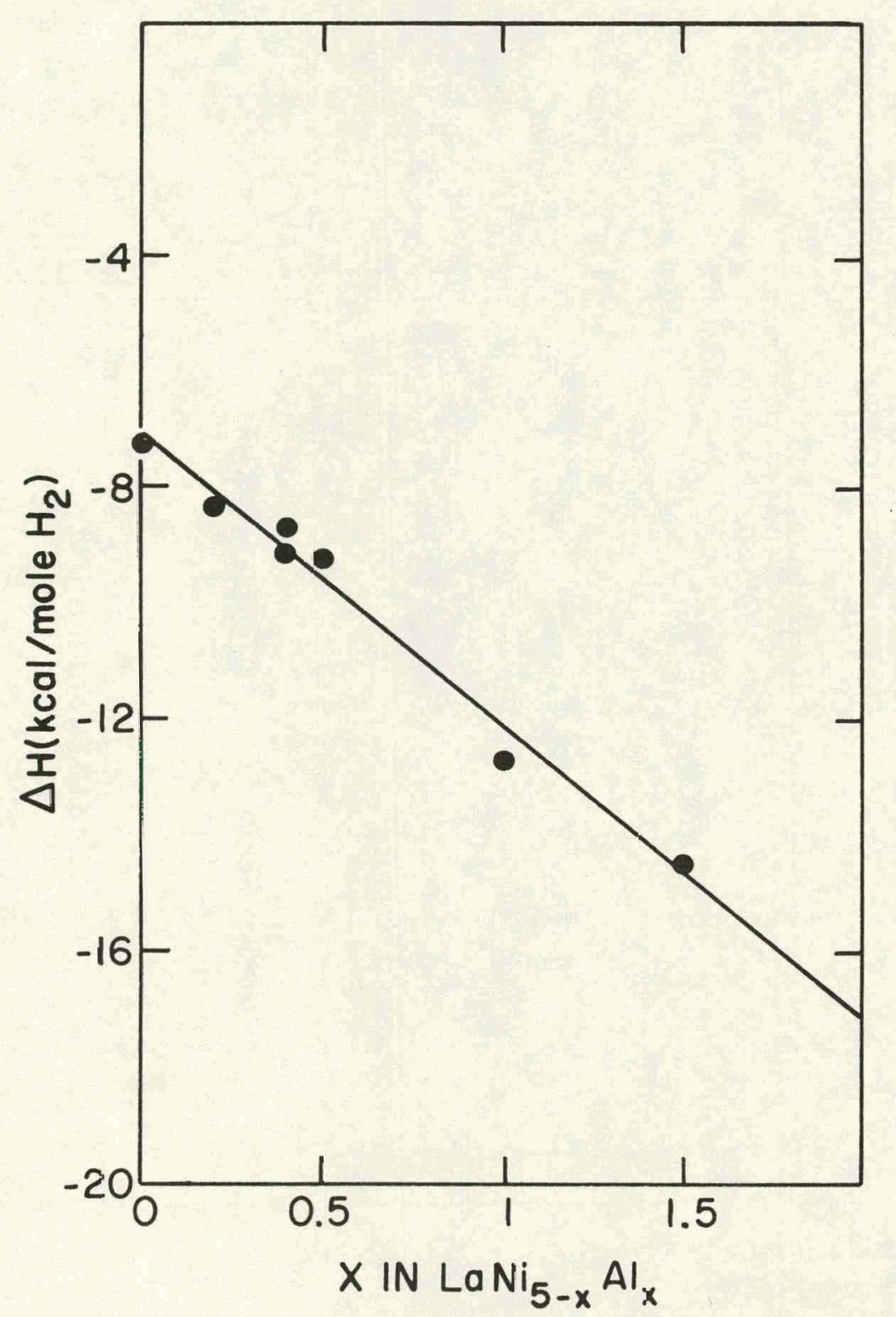

Fig. 3. Enthalpy Changes in Aluminum Substituted $\mathrm{LaNi}_{5}$

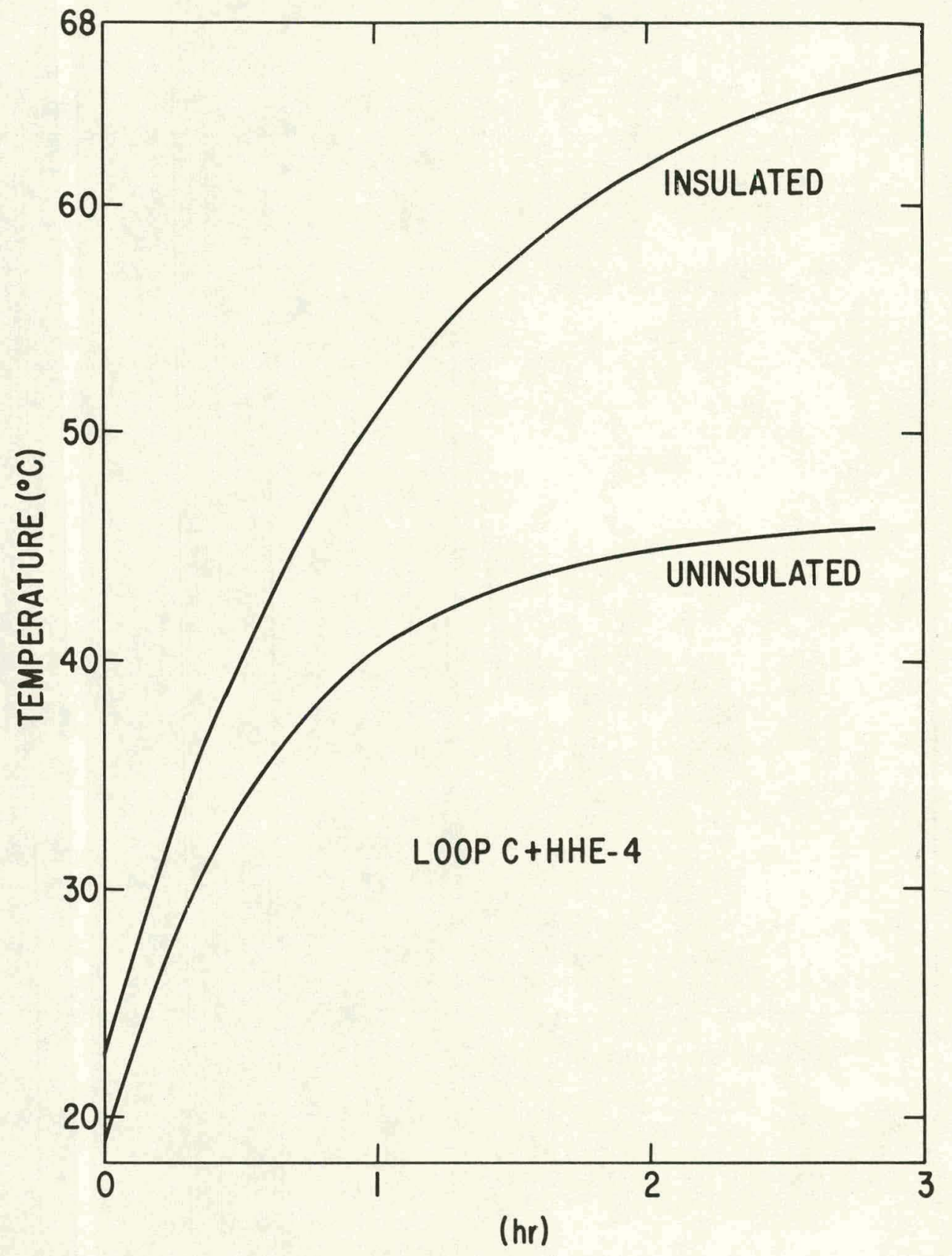

Fig. 4. Effect of Insulation on Heat Transfer Fluid System 


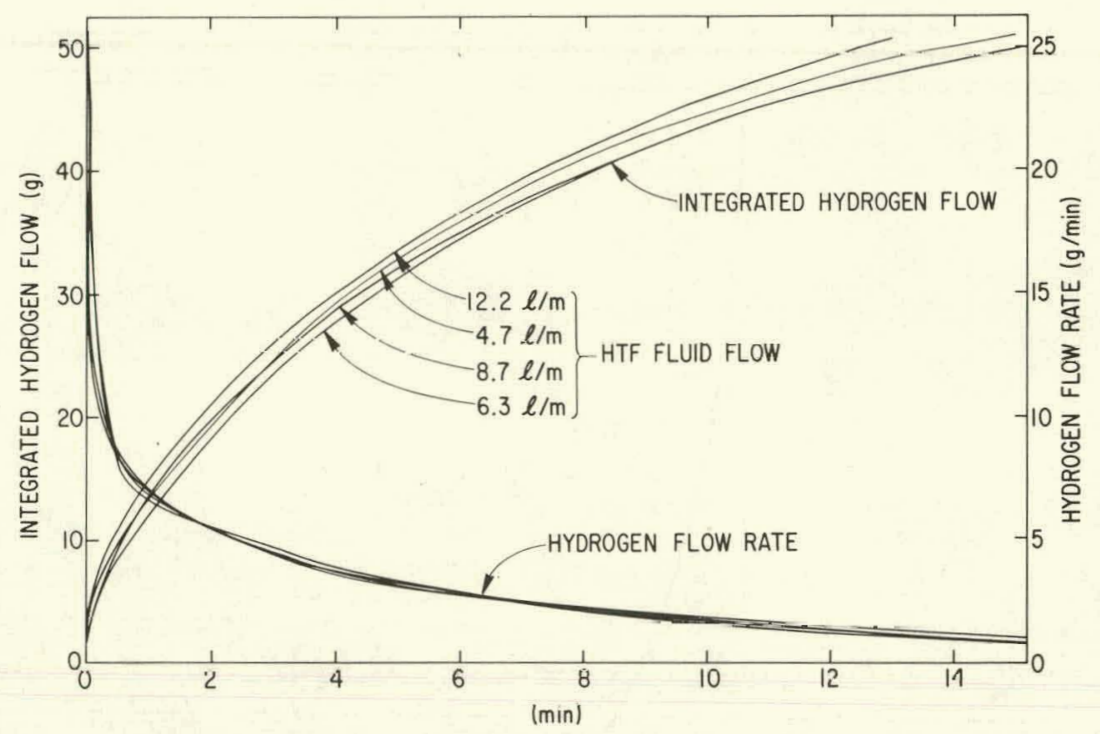

Fiy. 5. Heat Transfer Fluid Flow vs Hydrogen Transfer

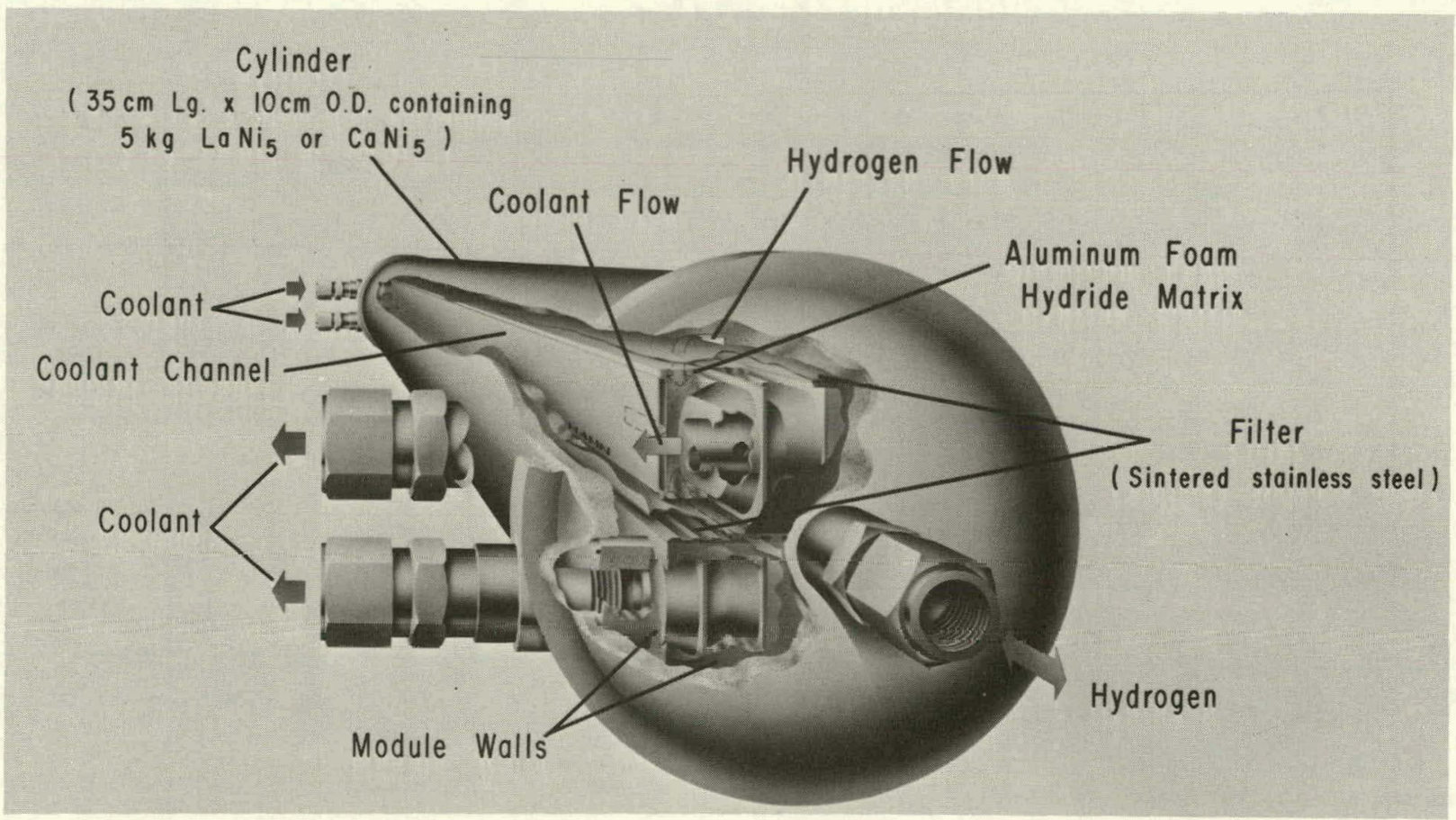

Fig. 6. Advanced Design Aluminum Foam Heat Exchanger 


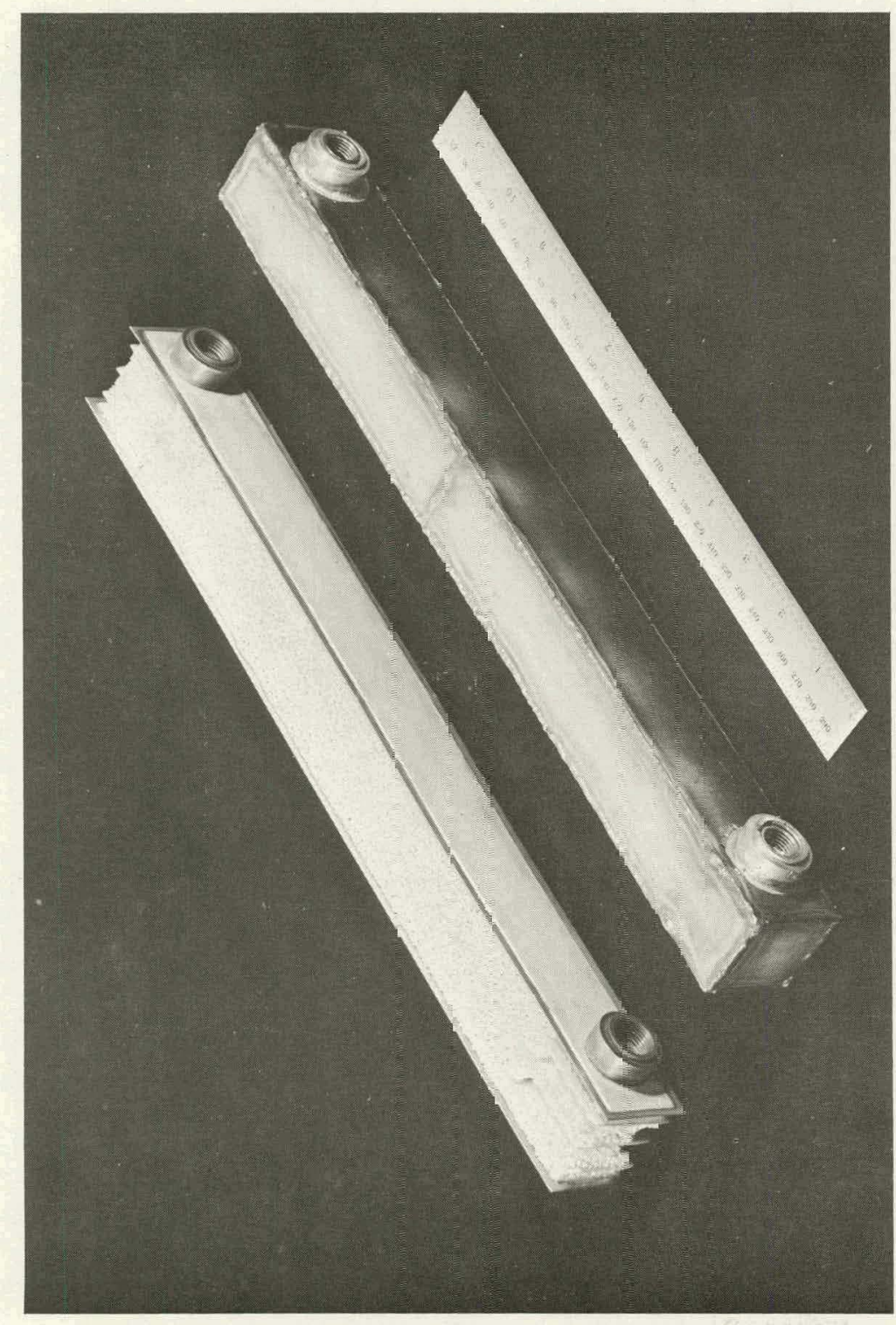

Fig. 7. Construction of fluminum Foam Heat Exchancer

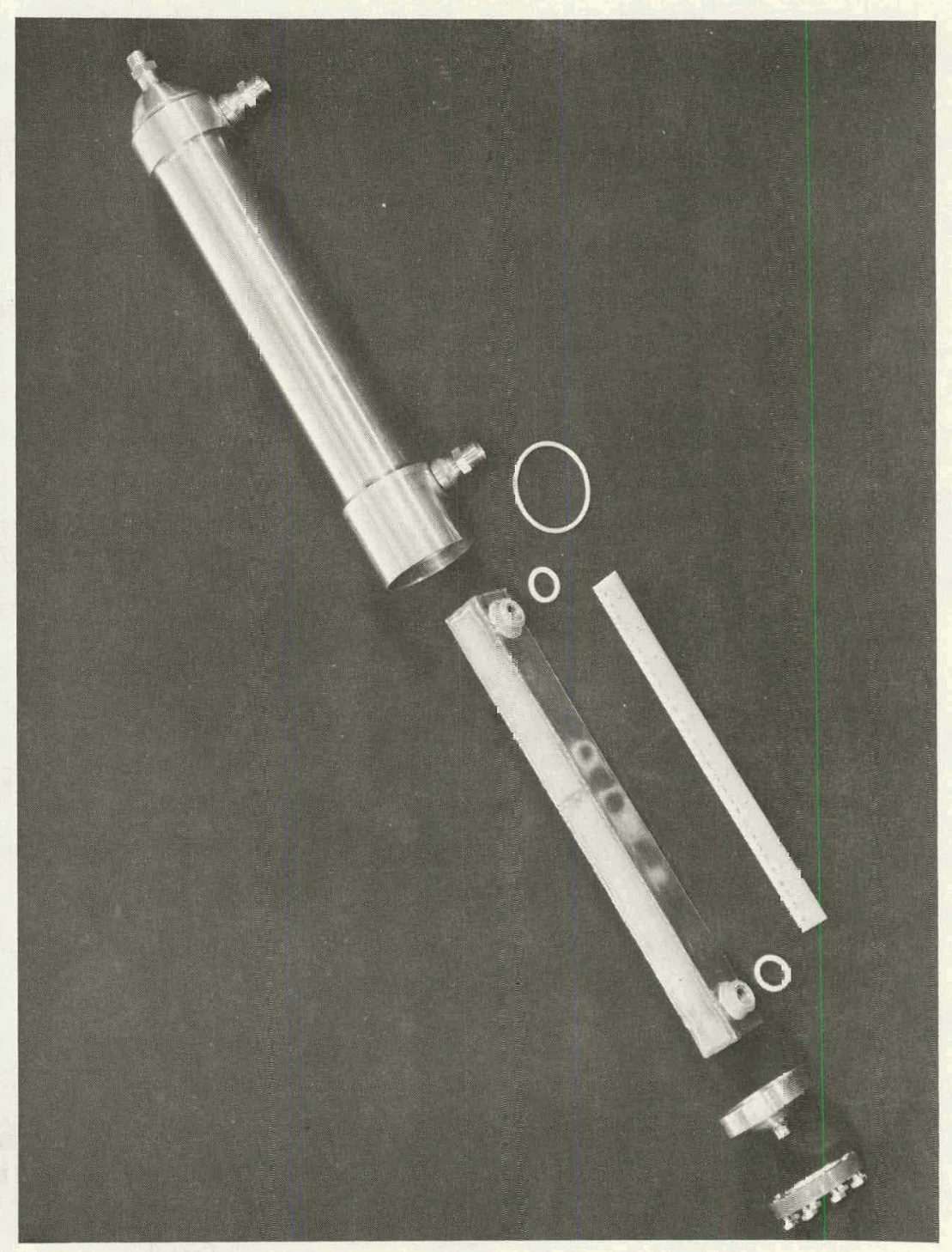

Fig. 8. Construction of Aluminum Foam Heat Exchanger 


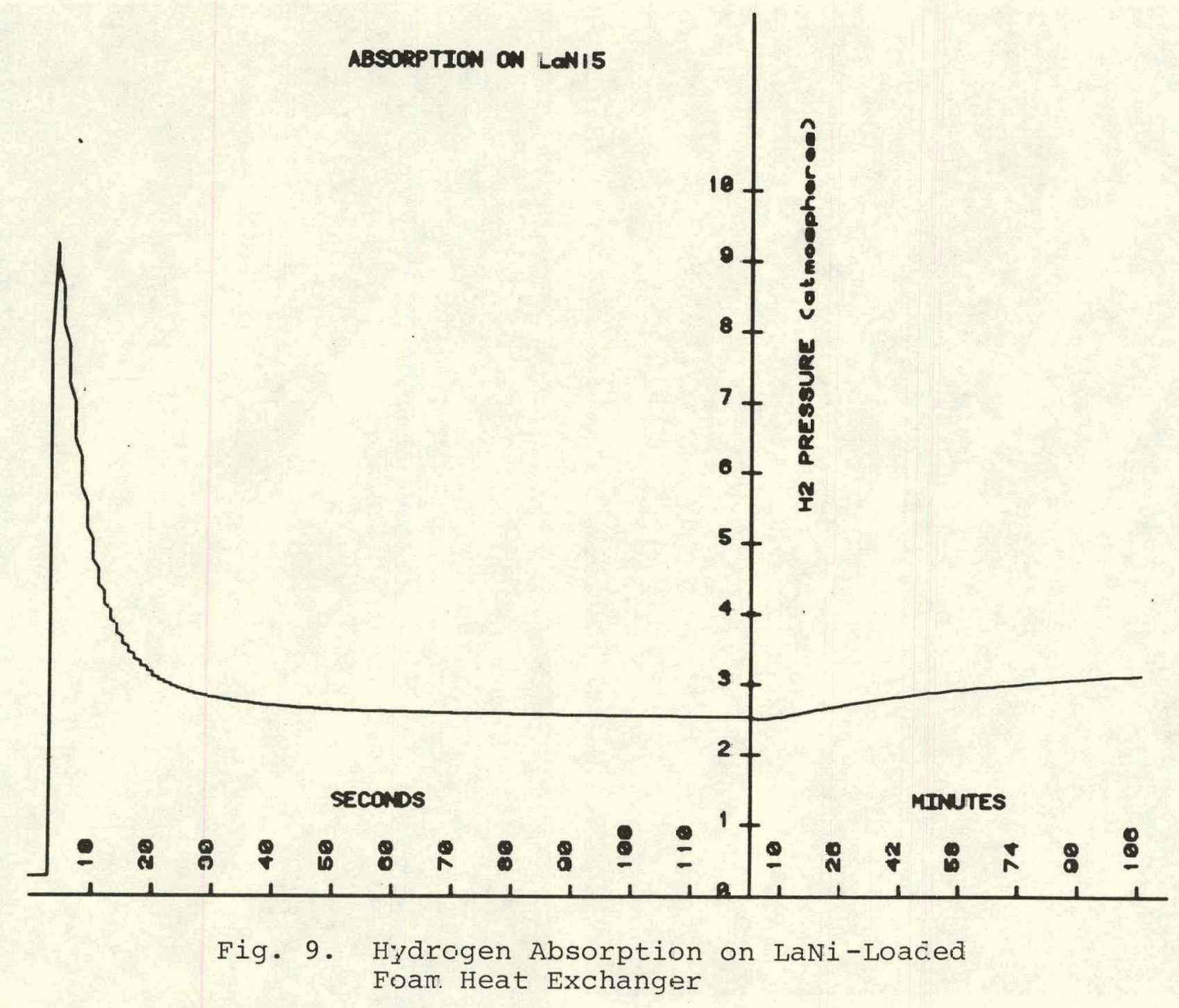




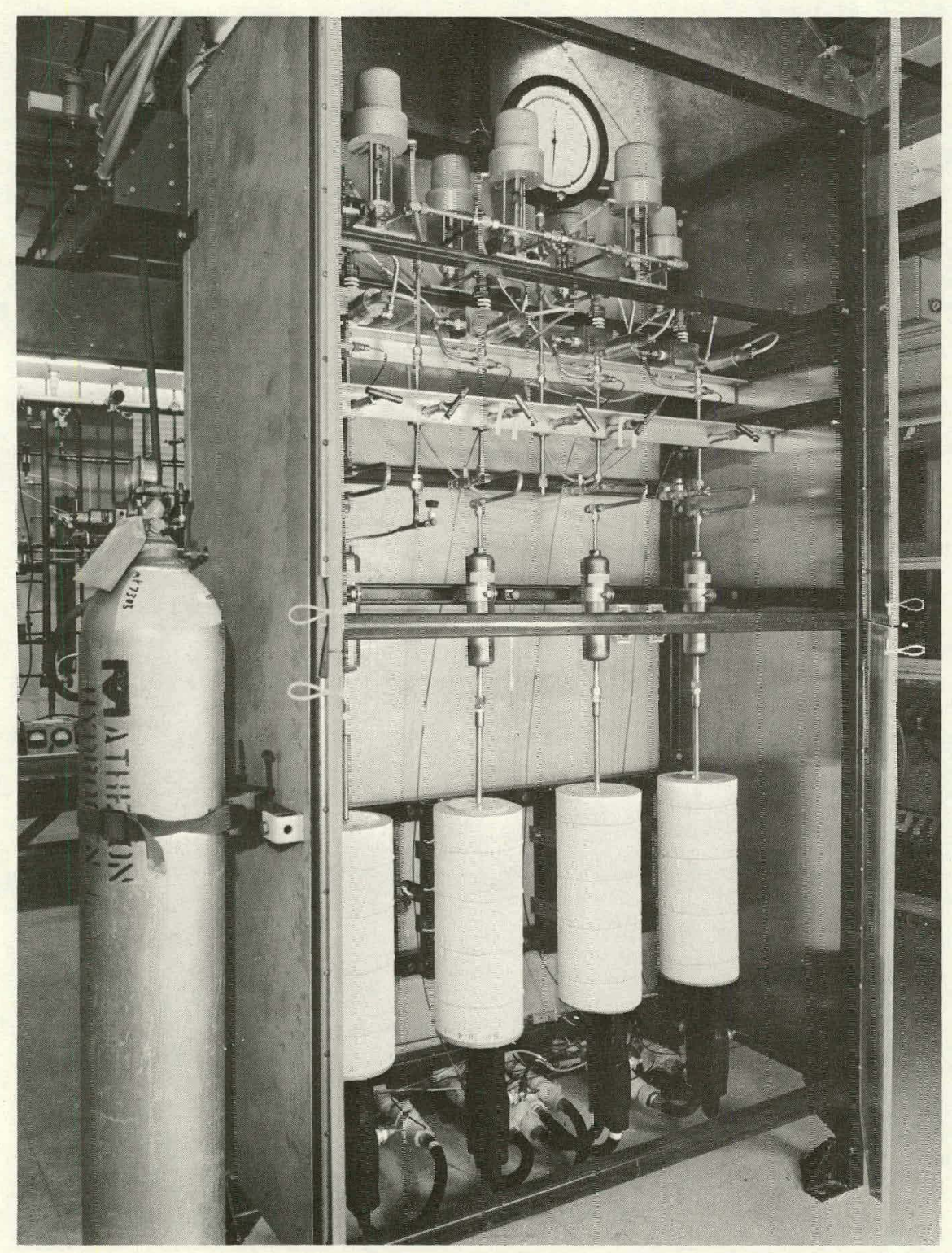

Fig. 10. Hydrogen System

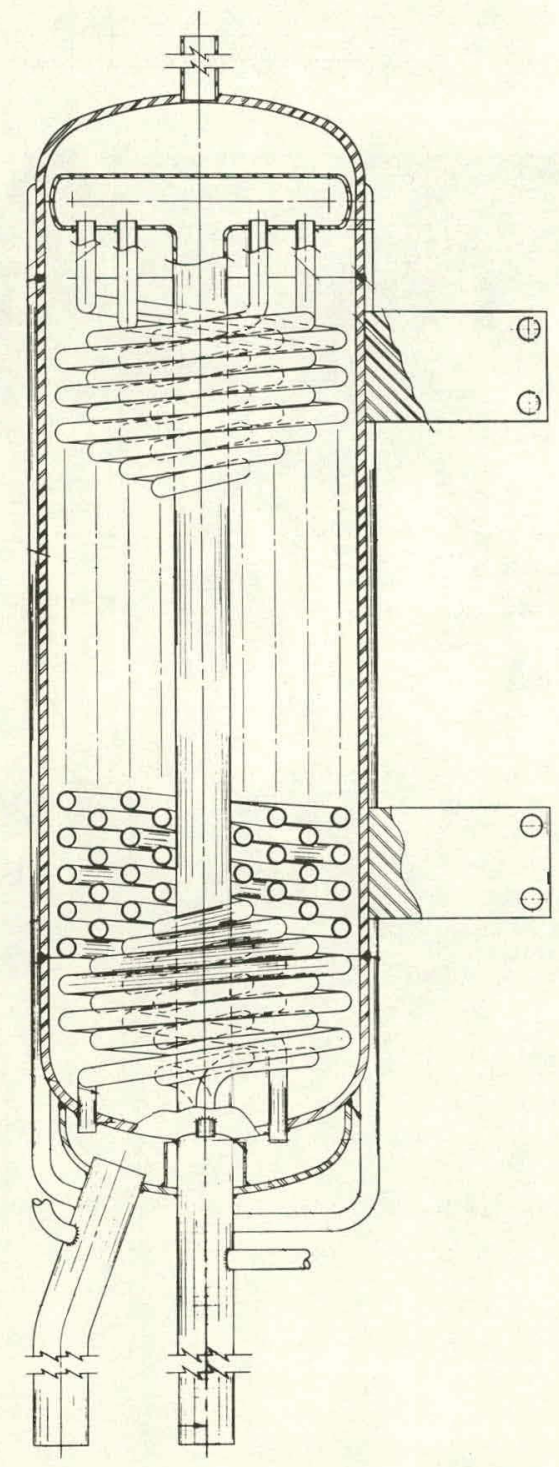

$\stackrel{v}{\omega}$
Fig. 11. Coileả Tubing Hydrogen Heat Exahanger 


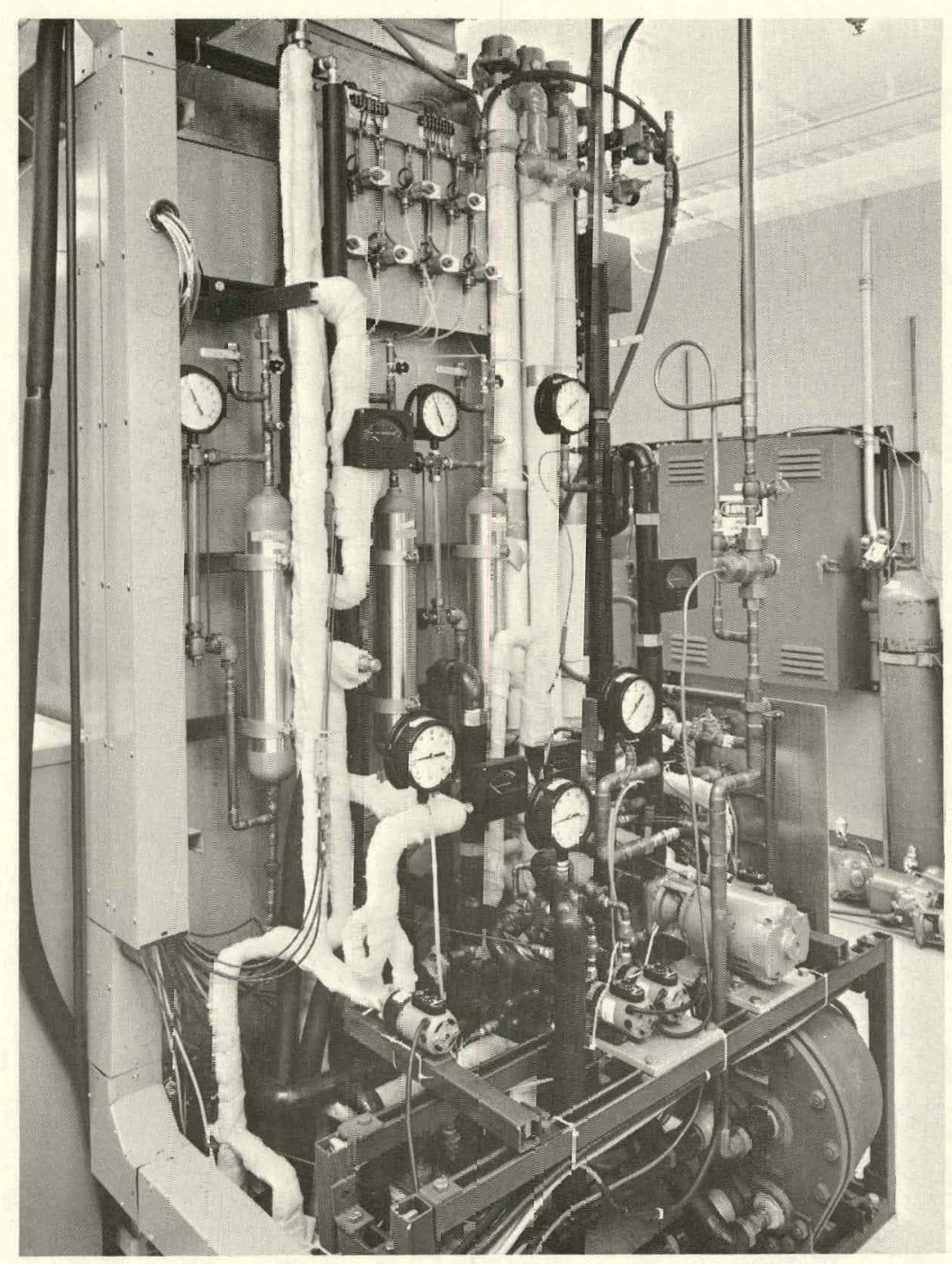

Fig. 12. Heat Transfer Fluid System

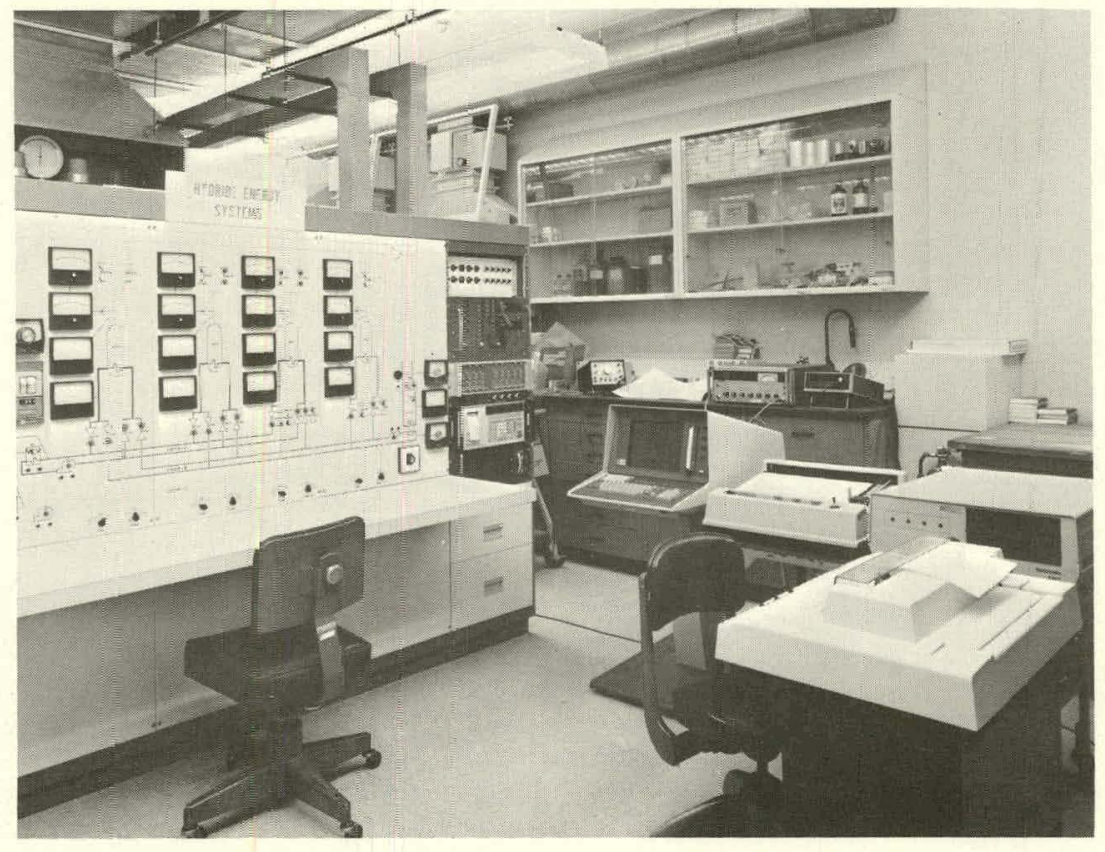

Fig. 13. Graphic Control Panel 

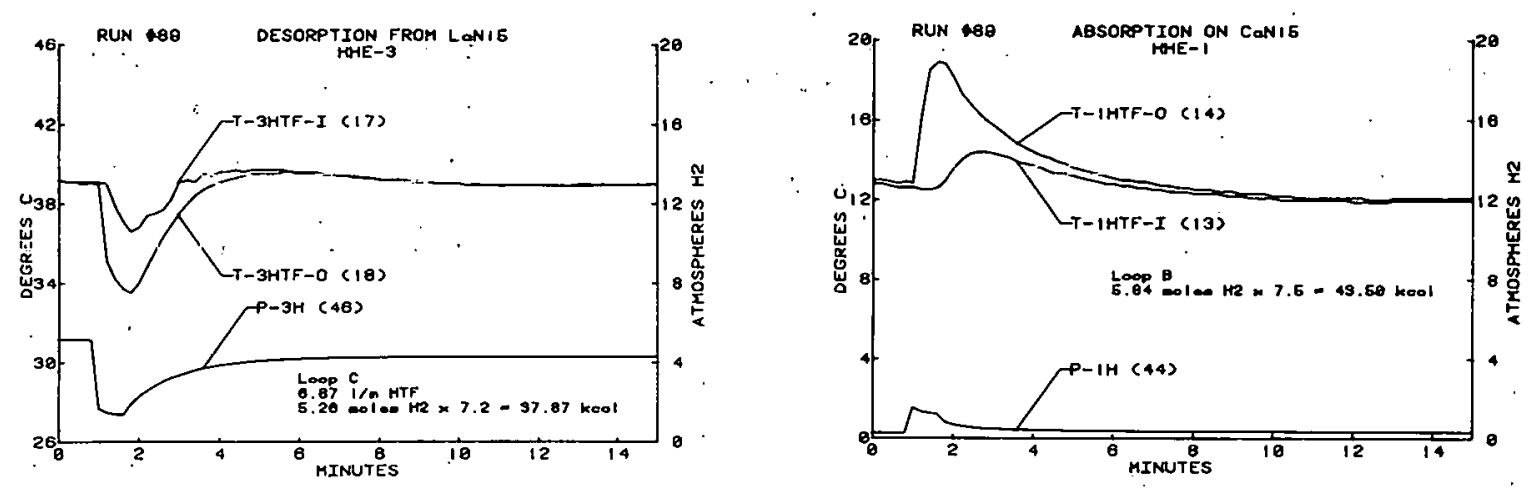

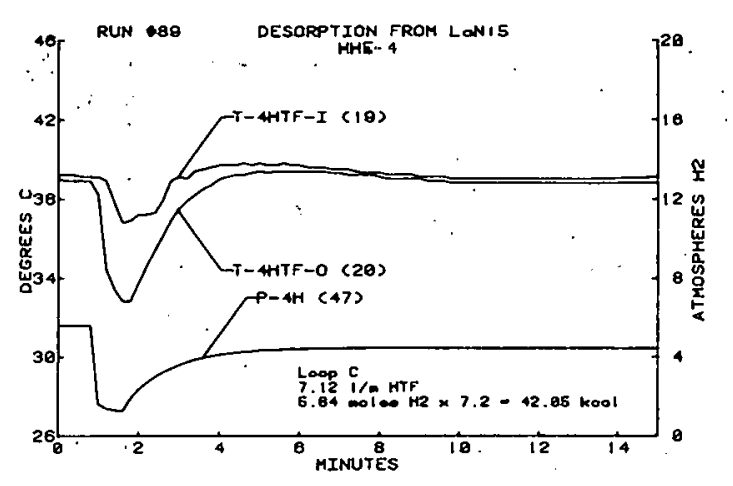

a

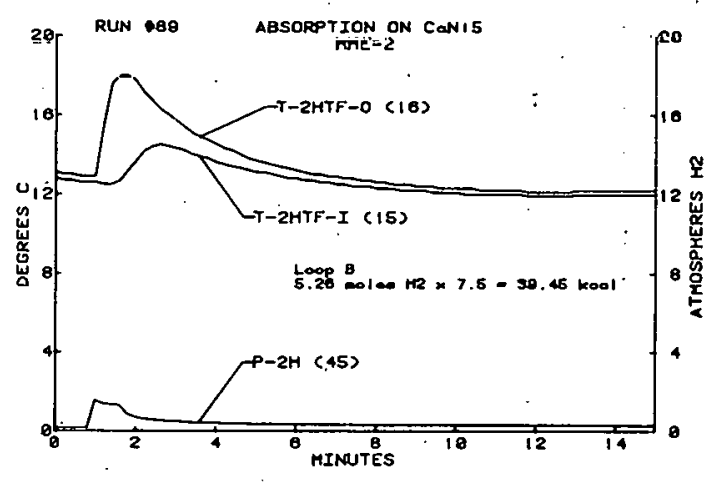

b

Fig. 14
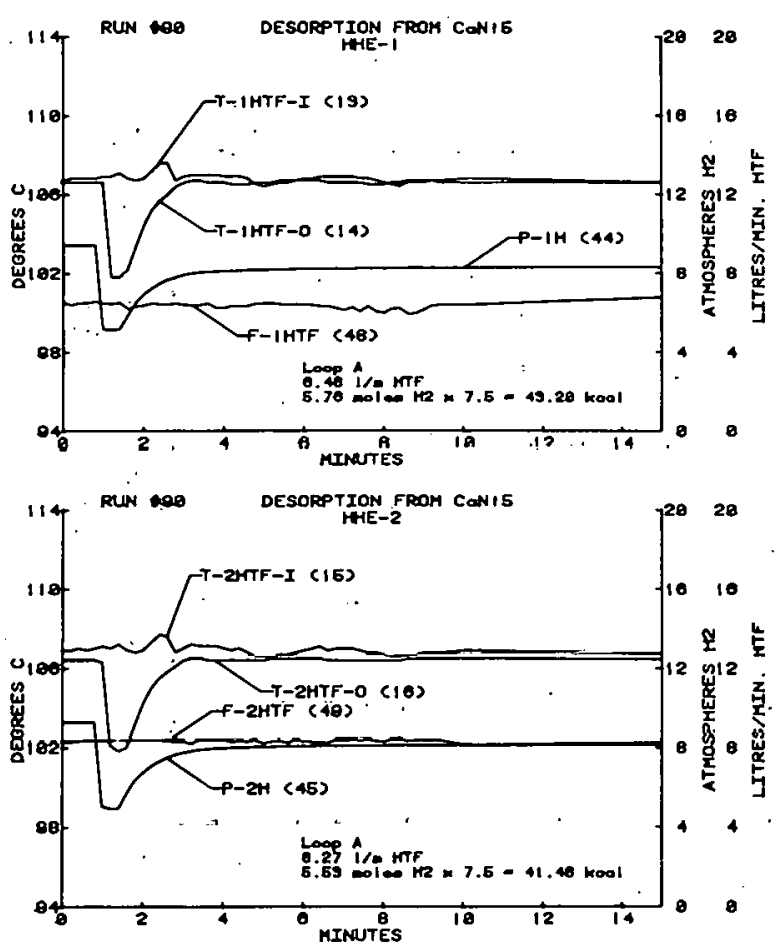

a
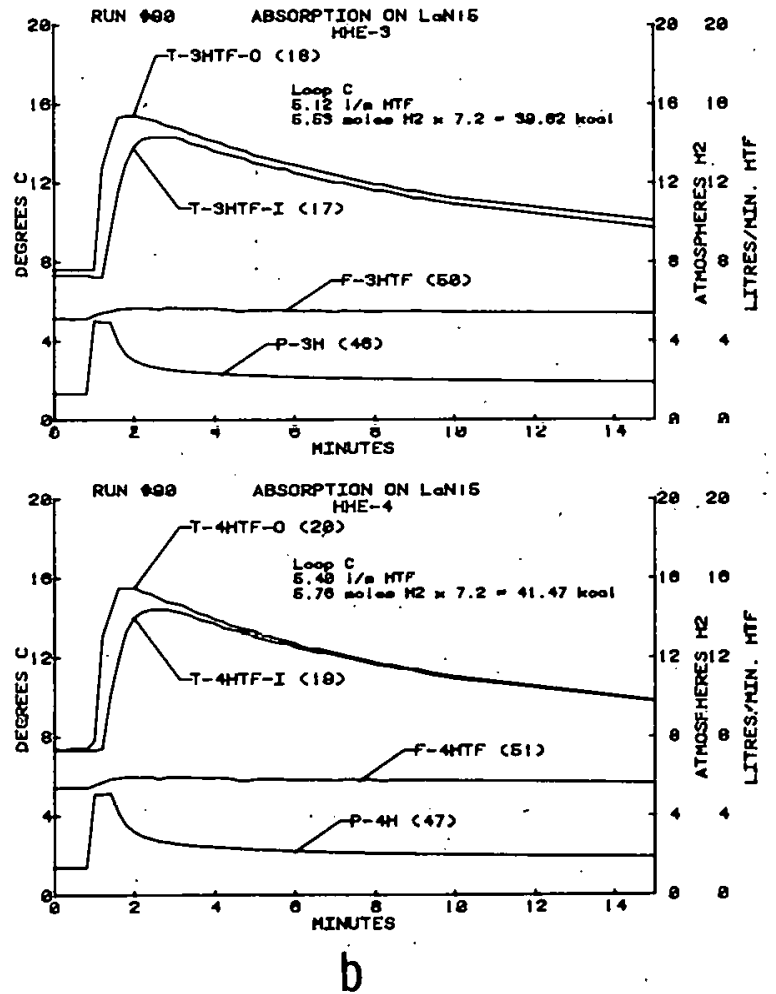

Fig. 15.

Performance of Old and New Alloy Beds 

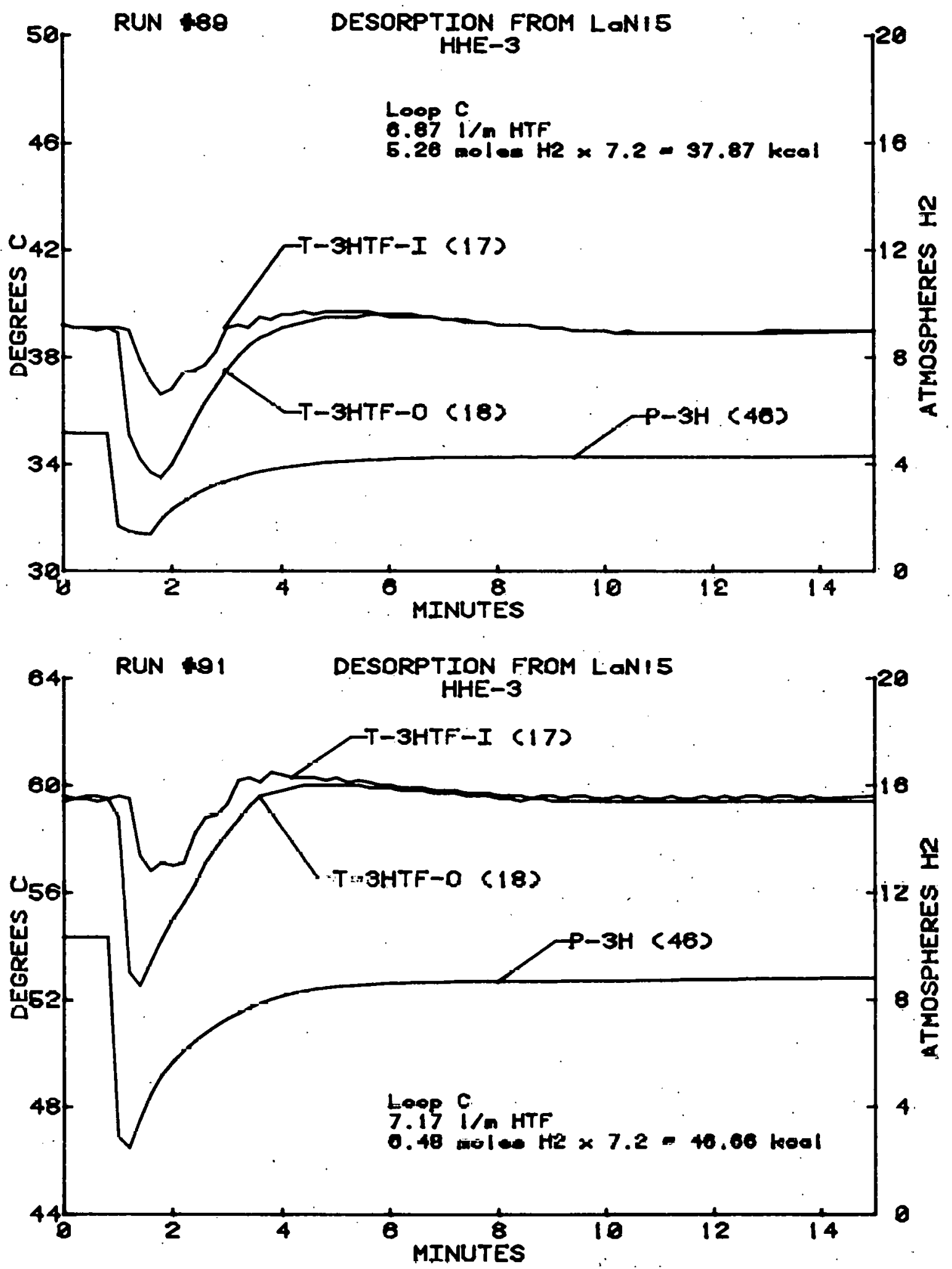

Fig. 16. Effect of Temperature on Hydrogen Desorption 

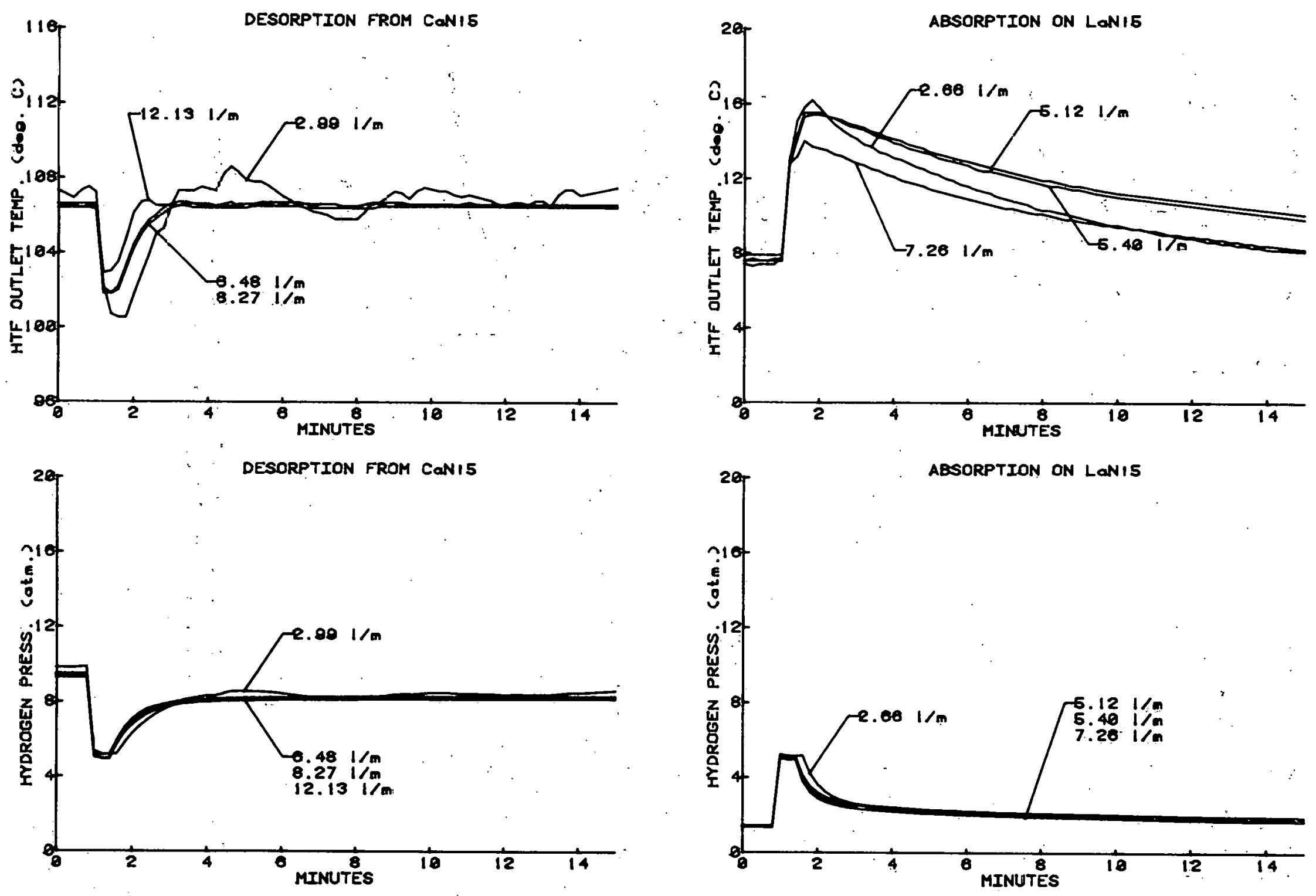

a

Fig. 17. Effect of Heat Transfer Fluid Flow Rate on Hydrogen Transfer 


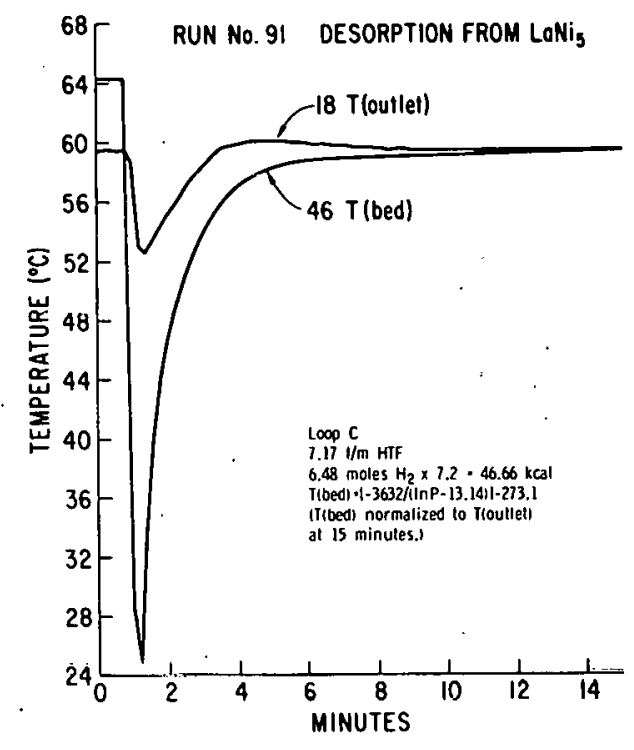

a

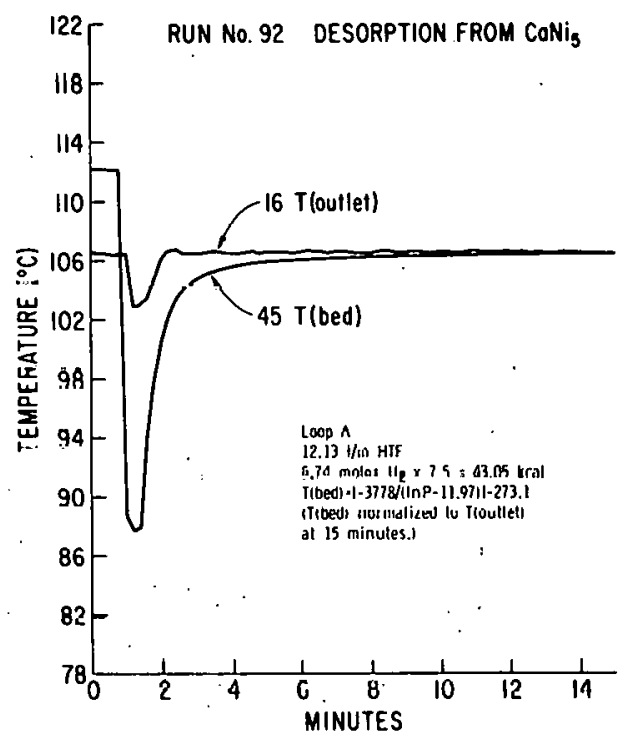

C

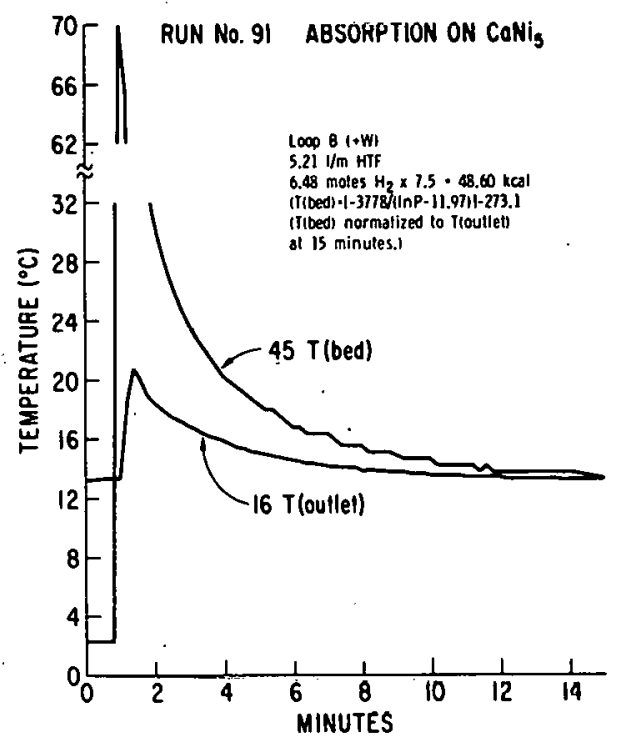

b

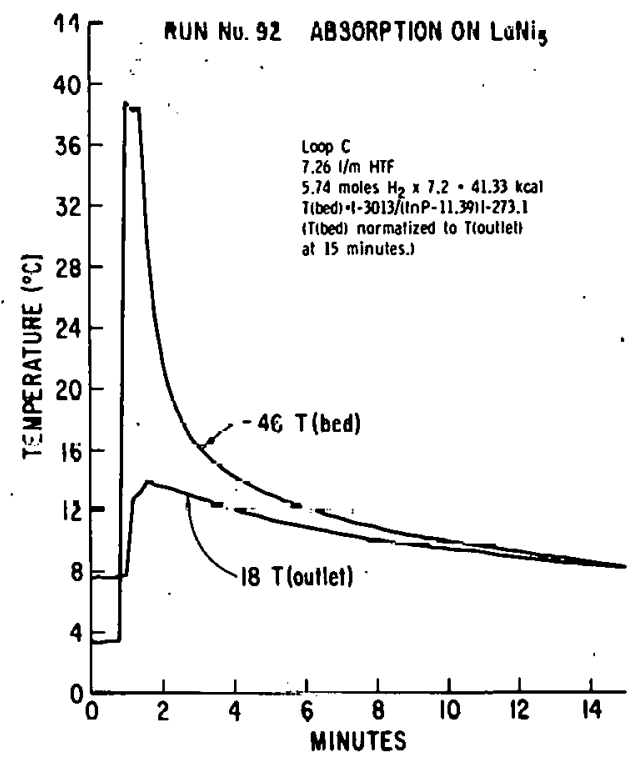

d

Fig. 18. Comparison of Hydride Bed and Exit Heat Transfer Fluid Temperature 


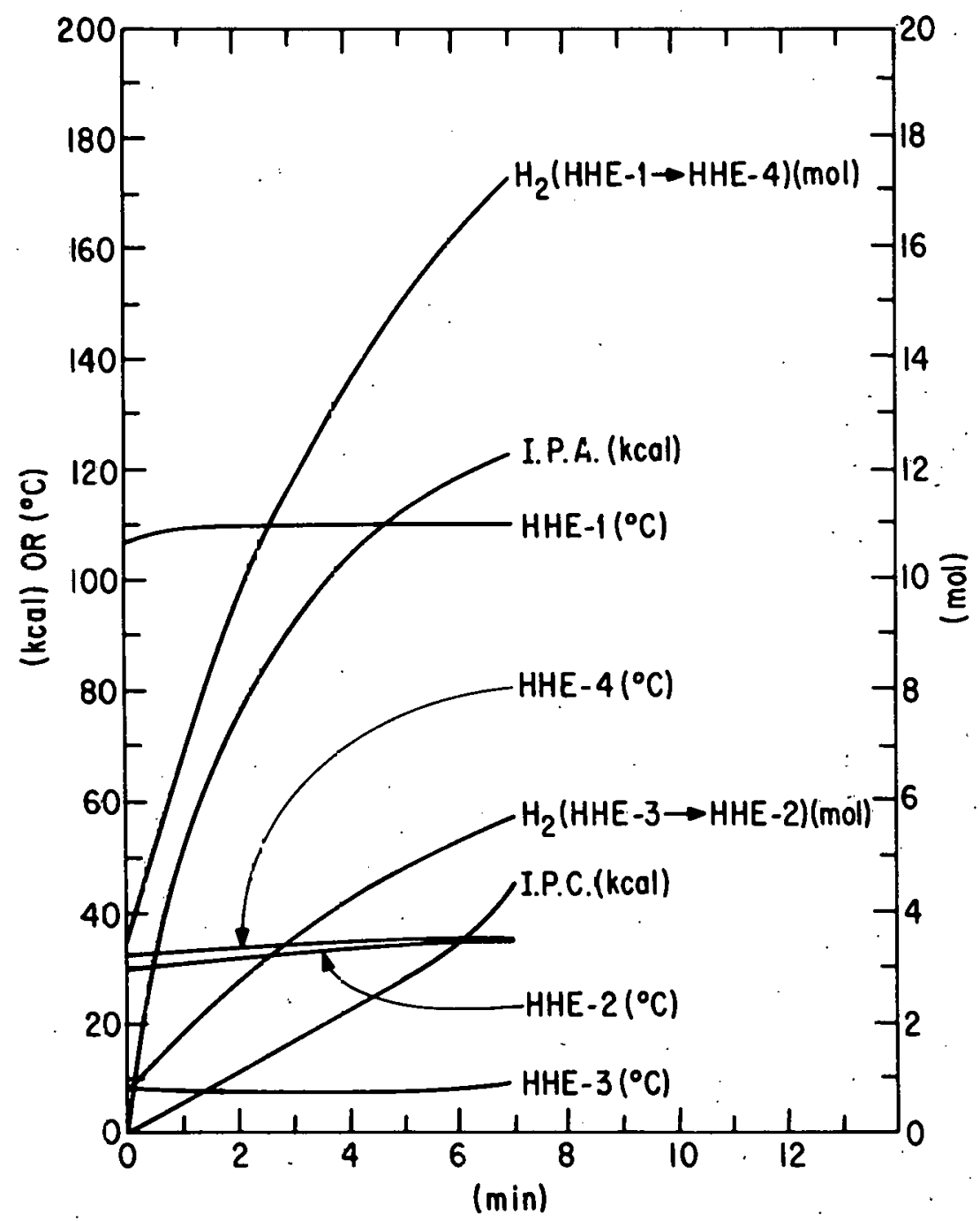

Fig. 19. Simulated Cooling Cycle I

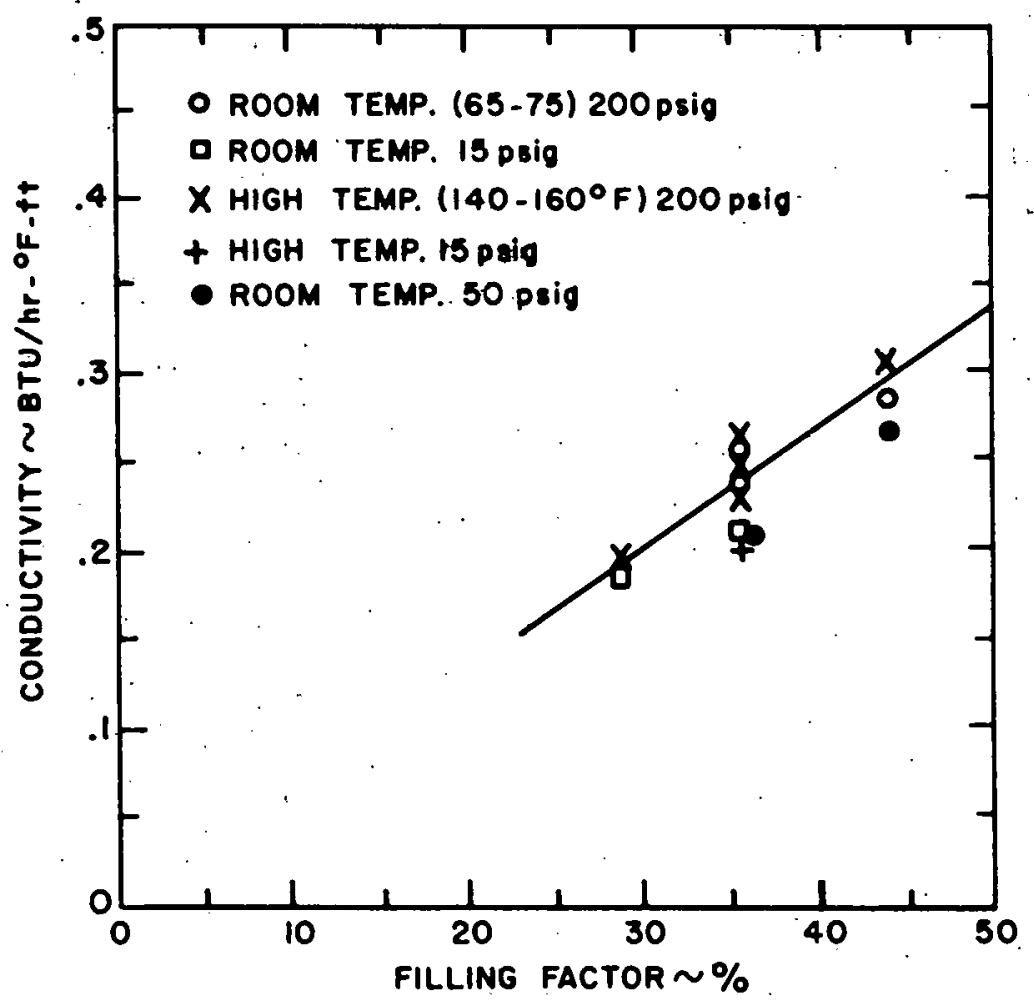

Fig. 20. LaNis Thermal Conductivity 
Distribution for ANL-79-8

Internal:

M. V. Nevitt

G. T. Garvey

E. G. Pewitt

E. J. Croke

P. F. Gustafson

P. Nelson

$\mathrm{J}$. Asbury

C. Blomquist

I. Sheft (229)

ANL Contract Copy

ANL Libraries (5)

TIS Files. ( 6 )

External:

DOE-TIC, for distribution per UC-94d (114)

Manager, Chicago Operations and Regional Office, DOE

Chief, Office of Patent Counsel, DOE-CORO

President, Argonne Universities Association

Chemistry Division Review Committee:

J. Bigeleison, State U. of Nêw York at Stuny Bruuk

F. A. Cotton, Texas A\&M U.

H. F. Franzen, Iowa State U.

H. S. Gutowsky, U. Illinois, Urbana

D. R. Herschbach, Harvard U.

E. L. Muetterties, U. California, Berkeley

F. S. Rowland, U. California at Irvine

T. T. Sugihara, Texas A\&M U.

J. H. Wang, State U. of New York at Buffalo 